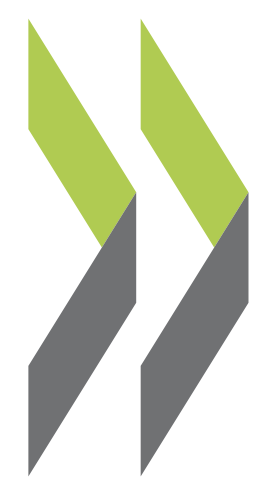

OECD Economics Department Working Papers No. 299

\title{
Encouraging \\ Environmentally Sustainable \\ Growth in Poland
}

Grzegorz Peszko,

Patrick Lenain 


\section{ENCOURAGING ENVIRONMENTALLY SUSTAINABLE GROWTH IN POLAND}

ECONOMICS DEPARTMENT WORKING PAPERS NO. 299

by

Grzegorz Peszko and Patrick Lenain

Most Economics Department Working Papers beginning with No. 144 are now available through OECD's Internet Web site at http://www.oecd.org/eco/eco/

\section{JT00109603}




\begin{abstract}
RÉSUMÉ
This paper reviews several aspects of Poland's environmental policies. Its main finding is that substantial progress has been made in dealing with the environmentally unfriendly legacy from the past. Poland has successfully combined emission permits based on environmental quality standards, emission fees and fines, public environmental subsidy schemes and widely publicised lists of the worst polluters. Other important factors of success were long-term time consistency, gradual tightening of enforcement and limited administrative discretion. Poland is now embarking on a fundamental revision of its instrument mix in order to respond to new environmental challenges typical of market economies, and to comply with the European Union environmental Directives. In this context, the challenge is to formulate a medium-term strategy that is both environmentally effective and market friendly. Pending legislative amendments, however, may not always live up to this challenge. New instruments under development seem to rely excessively on technology standards that may be both environmentally ineffective and economically inefficient, on excessive subsidies, as well as on undue administrative discretion. The paper proposes alternative developments in policy instruments, such as the introduction of a system of tradable emission permits, a streamlining of environment fees, a phasing-in of elements of green tax reform and a new role for the Environment Funds. Notwithstanding these policy changes, large public investments will need to be made in the context of accession to the European Union, in particular in public environmental infrastructure. Ensuring financing and affordability of these investments will be difficult. Poland could overcome this difficulty by applying three criteria: public investments should be made in a cost-effective manner, fees for using environmental infrastructure should be brought closer to cost-recovery levels, and the private sector should play a greater role as a financier or service provider.
\end{abstract}

JEL classification: H23, Q00, Q20, Q28, Q40, Q48

Key words: Environment, Poland

Ce document examine plusieurs aspects de la politique de l'environnement de la Pologne. Sa conclusion principale est que des progrès significatifs ont été réalisés pour faire face à l'héritage environnemental encombrant du passé. La Pologne a combiné avec succès l'usage de permis d'émission basés sur des normes environnementales, des redevances et des amendes portant sur les émissions, des subventions publiques à l'environnement, et la publication de listes des pires pollueurs. D'autres facteurs importants de succès ont été la cohérence à long terme de la politique de l'environnement, le renforcement graduel de sa mise en application et le degré limité d'arbitraire dans les décisions administratives. La Pologne se lance désormais dans une refonte fondamentale de son dosage d'instruments afin de mieux répondre aux défis posés par le passage à une économie de marché, et afin de se mettre en conformité avec les Directives environnementales de l'Union européenne. Dans ce cadre, le défi est de formuler une stratégie de moyenterme qui soit à la fois efficace sur le plan de l'environnement et favorable au marché. Les amendements législatifs en cours de discussion ne répondent toutefois pas toujours à ce défi. Les nouveaux instruments en cours d'élaboration semblent reposer de façon excessive sur des standards technologiques, ce qui n'est pas efficace sur le plan à la fois de l'environnement et de l'économie, sur des subventions excessives, et sur un degré d'arbitraire dans les décisions administratives. Le présent document propose plusieurs voies alternatives pour le développement des instruments de la politique de l'environnement, telles que l'introduction d'un système de permis d'émission négociables, la simplification des redevances d'émission, l'introduction graduelle d'une éco-fiscalité, et un nouveau rôle pour les Fonds pour l'Environnement. En dépit de ces réformes, des investissements publics importants devront être effectués pour l'adhésion à l'Union européenne, en particulier pour les infrastructures publiques de protection de l'environnement. Il sera difficile de financer ces investissements et d'en maitriser le coût. La Pologne devrait néanmoins y parvenir en appliquant trois critères : les investissements publics devraient être faits avec le souci d'un bon rapport coût-efficacité, les redevances pour l'utilisation des infrastructures environnementales devraient être relevées afin de mieux recouvrir les coûts, et le secteur privé devrait jouer un rôle plus actif en tant que financier et prestataire de services.

Classification JEL : H23, Q00, Q20, Q28, Q40, Q48

Mots clés : Environnement, Pologne

Copyright OECD, 2001

Applications for permissions to reproduce or translate all, or part of, this material should be made to: Head of Publications Service, OECD, 2 rue André-Pascal, 75775 Paris Cedex 16, France. 


\section{TABLE OF CONTENTS}

ENCOURAGING ENVIRONMENTALLY SUSTAINABLE GROWTH IN POLAND............................4

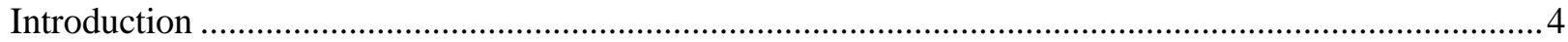

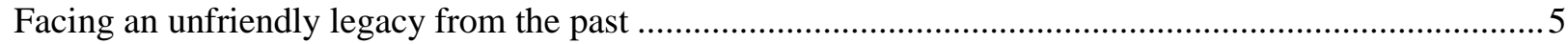

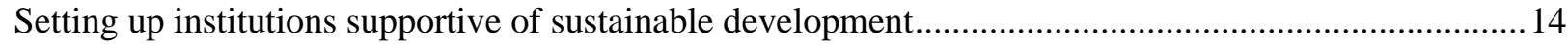

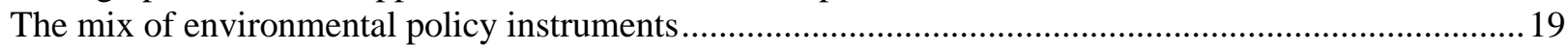

How to undertake the environmental clean-up required by the EU?

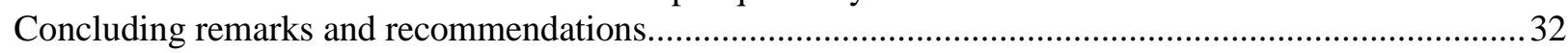

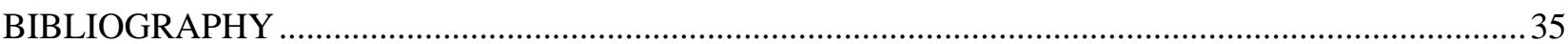

\section{Boxes}

Box 1. Key government environmental institutions and their main responsibilities ............................... 16

Box 2. Attempts to integrate environmental objectives into other policies: failures and successes..........17

Box 3. Environment Funds in "advanced " OECD countries versus Polish Environment Funds ..............18

Box 4. Mixing economic instruments and technology standards .........................................................2 20

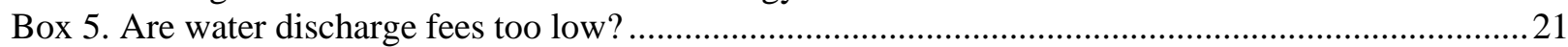

Box 6. Have air emission charges in Poland encouraged emissions reduction? ......................................23

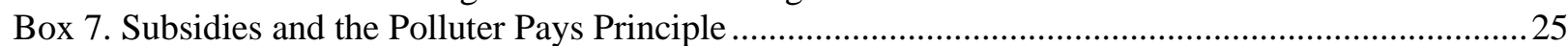

Box 8. How to abate pollution from large combustion plants in a cost-effective manner?......................28

Box 9. How to assess the economic benefits of environmental policies? .............................................31

Box 10. Recommendations on environmentally sustainable growth ......................................................33

\section{Table}

1. Investment expenditure required for EU accession in environmental protection

\section{Figures}

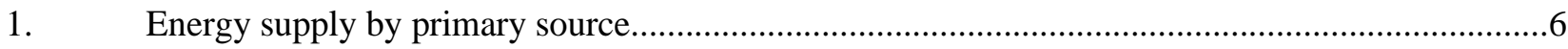

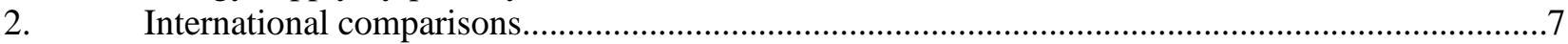

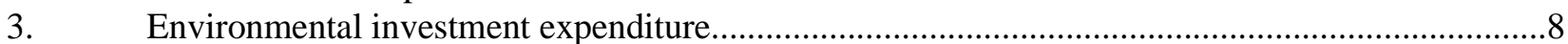

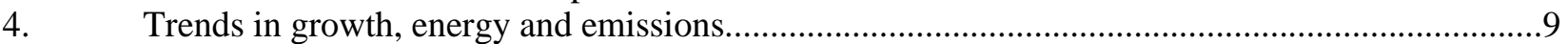

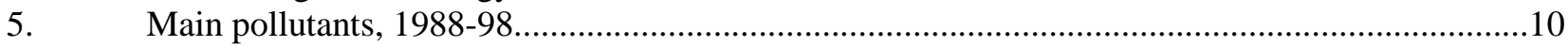

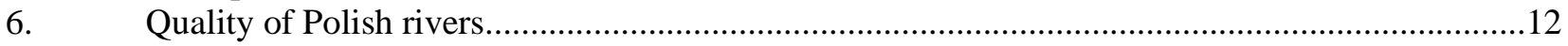

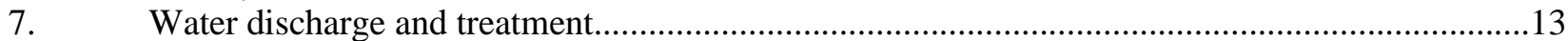

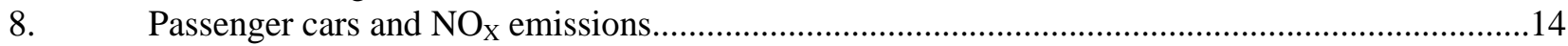

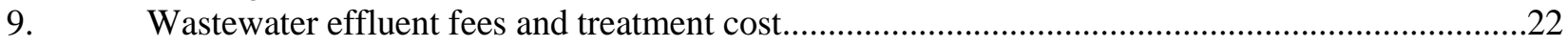

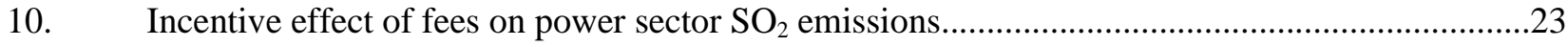

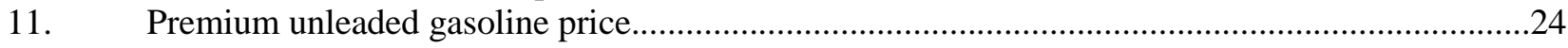




\title{
ENCOURAGING ENVIRONMENTALLY SUSTAINABLE GROWTH IN POLAND
}

\author{
Grzegorz Peszko and Patrick Lenain ${ }^{1}$
}

\section{Introduction}

1. Poland has inherited from the past an economic structure that was planned with little consideration for the environment. Industries in the sectors of coal extraction, steel and iron, and energy generation produced vast amounts of air pollutants, dust and solid waste. Little municipal equipment was available to collect and treat used waters and manage waste produced by cities and rural settlements. Faced with this unfriendly legacy from the past, environmental policies have actively sought for the last decade to reduce the pressure stemming from existing sources. Notwithstanding remarkable reductions in emissions of several pollutants, Poland's environmental indicators continue to be among the worst in the OECD area, given its state of development. In addition to remaining pressures exercised by "old" industries, there are also signs that the rapid growth of output and consumption are generating new environmental damages. The huge increase in the number of passenger cars is degrading the quality of ambient air in large cities. Construction of new roads, housing and commercial estates is competing with the desire to protect pristine natural areas. Packaging materials typical of the new consumption patterns are accumulating unrecycled in city dumps.

2. In these circumstances, the challenge for the future will be to achieve a socially desirable rapid growth in living standards, while at the same time reducing the pressure on environmental resources. After reviewing the existing situation, this paper discusses policies that would be necessary to make further progress in this direction. No attempt is made here to provide a comprehensive review of environmental issues, the purpose of the last Environmental Performance Review (OECD, 1995a). Thus, a number of

1. Grzegorz Peszko is an Administrator in the Environment Directorate, and Patrick Lenain was a Principal Economist in the Economics Department. An earlier version of this paper served as input into the 2001 OECD Economic Survey of Poland, which was published in April 2001 under the authority of the Economic and Development Review Committee. The authors would like to acknowledge the assistance of the Polish authorities, especially the Ministry of the Environment and the Ministry of Economy, in the preparation of this paper. They would especially like to acknowledge the assistance of the Department of Foreign Relations of the Ministry of the Environment, the Department of Economic Strategy of the Ministry of Economy, the National Fund for Environment Protection and Water Management, the Tax Department of the Ministry of Finance, the Polish Delegation to the OECD, the Department of Environmental Protection of the Voivod Office in Krakow, and the Krakow Fund for Environmental Protection and Water Management. Special thanks go to Czeslaw Więckowski and Karol Litynski who provided invaluable inputs to the paper. Substantive inputs by Krzysztof Berbeka and Jochem Jantzen are also gratefully acknowledged. Without implicating them, the paper benefited from comments of Christian Averous, Nils Axel Braathen, Jean-Philippe Barde, Andrew Dean, Jorgen Elmeskov, Mike Feiner, Brendan Gillespie, Rauf Gonenc, Yutaka Imai, Robert Krzyskow, Paul O’Brien, Tomasz Podgajniak, Jerzy Sleszynski, Heino Von Meyer, Ann Vourc'h, Stanislaw Wajda, Joke Waller-Hunter and Tomasz Zylicz. Special thanks also go to Roselyne Jamin, Agnieszka Markowska and Dariusz Szwed for research assistance and to Nadine Dufour and Chrystyna Harpluk for secretarial assistance. 
topics are deliberately left aside, such as the increasing amounts of industrial waste, the management of forests and biodiversity, and the environmental impact of the future modernisation of Polish agriculture. Instead, after a brief summary of environmental trends, this chapter focuses on i) the architecture of an institutional framework conducive to a sustainable development, ii) the right choice of environmental policy instruments, and iii) the challenges posed to environmental policy by accession to the European Union (EU). A list of concrete recommendations is provided at the end of the paper.

\section{Facing an unfriendly legacy from the past}

3. Like many other former centrally planned economies, Poland inherited from the past an environmentally unfriendly economic structure. The system of incentives did not encourage efficient and sustainable use of natural resources. Industrial policies had led to large investment in industrial structures, such as iron and steel, diverting resources away from important public infrastructures, such as sewage systems and water treatment plants.

\section{Pressure stemming from the "old" economy}

4. One of the most damaging inherited pressures stems from the combined industry of coal mining, electricity generation, base chemistry and metals milling. The coal industry has always been, and still is, the main source of environmental stress in some parts of the country. Although coal is one of the dirtiest fossil fuels, it is exempt from indirect taxes (except for the tax-deductible VAT), which encourages its use as a primary energy source by power generation plants, steel mills and for heating purposes (Figure 1). While OECD countries have to a large extent switched to sources of energy that release less emissions of traditional air pollutants into the air (such as nuclear power, natural gas or renewable energies), Poland still relies heavily on coal and lignite. Remarkable reductions of emissions have been achieved from the old heavy industry complex, e.g. steel mills. (Ministry of Economy, 1998). However, the ecological impact of the industry is still severe due to its concentration in the southern part of the country. In addition to local pollution, the energy and industrial sectors also produces large quantities of greenhouse gases, which affect global climate. Poland ranks among the largest producers of carbon dioxide in relation to GDP (Figure 2). In 1997, Poland released into the atmosphere 361 million tonnes of CO2, about 3 per cent of total OECD emissions, compared to the GDP share in OECD of 1.3 per cent $^{2}$.

5. Over the last two decades, under strong pressure by the public, policy-makers have started to address the most compelling problems. Environmental policy has incited polluters to cut down the most dangerous emissions, lower the use of non-renewable resources and, more generally, pay more attention to negative externalities. Part of this new approach has consisted in closing down the worst sources of pollution. In the period 1992-1998, the State Environmental Inspectorate shut down the operations of 136 plants (Wajda, 2000). More constructively, environmental policy has encouraged polluters to invest in environmental protection equipment. In 1998, total investment expenditure in the area of environmental protection amounted to Zl 9 billion $^{3}$ (Figure 3). Compared to 1991, annual environmental investments increased by 1.8 times in real terms. ${ }^{4}$ In comparison to other OECD countries, this flow of environmental protection investments is significant both in relation to GDP (1.6 per cent) and as a share of total

2. GDP at purchasing power parity in 1995.

3. The data mentioned in this paragraph are mostly taken from: Central Statistical Office (1999): "Environmental Protection in Poland", in Quarterly Statistics Volume VII, No3, December, Warsaw.

4. $\quad$ After adjusting for a change in the definition in 1996. 
investment expenditure (8-9 per cent) $)^{5}$. The largest environmental protection investments are made by enterprises to control emissions of pollutants into the atmosphere and by municipalities to reduce the discharge of wastewater.

Figure 1. Energy supply by primary source

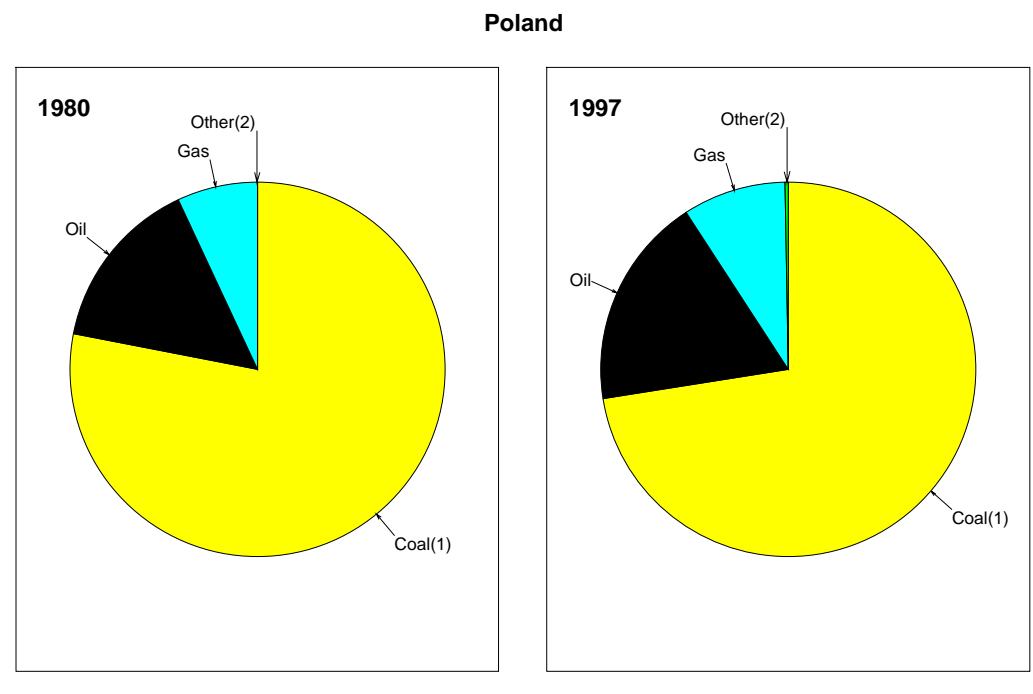

OECD
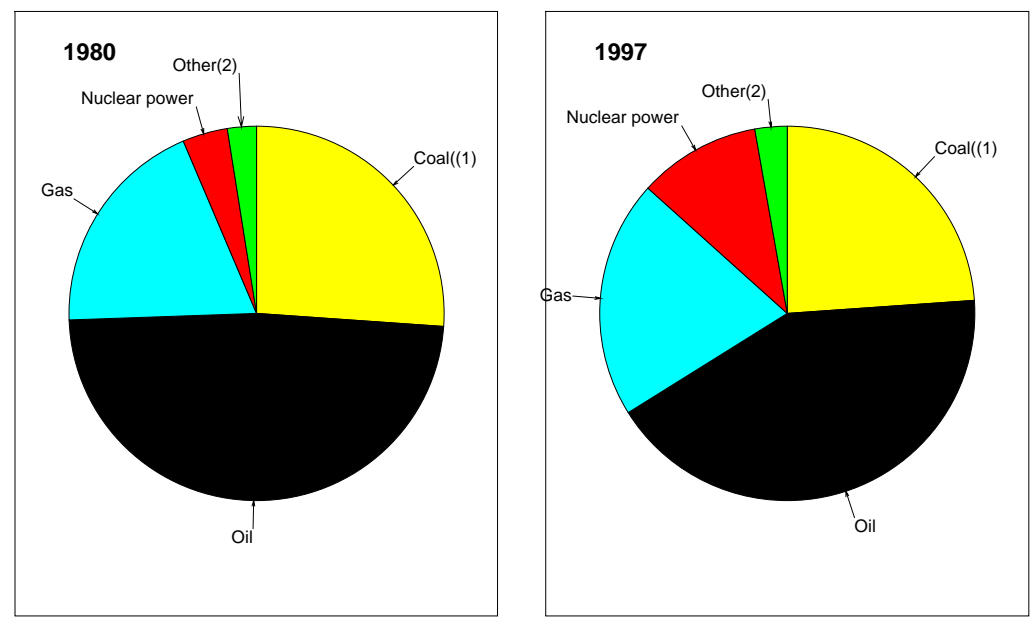

1. Also includes combustible renewables and waste. 2. Hydro, geothermal ans solar energy. Source: OECD, OECD Environmental data, compendium 1999

5. International comparisons of environmental expenditure are difficult because different countries use different coverage and different definitions, sometimes diverging from the OECD standards. For example, GUS changed expenditure classification in 1996, rendering the later data not directly comparable with those from before. Not all new investment expenditure categories are considered "environmental" by OECD definitions. 
Figure 2. International comparisons

1997 or latest available year
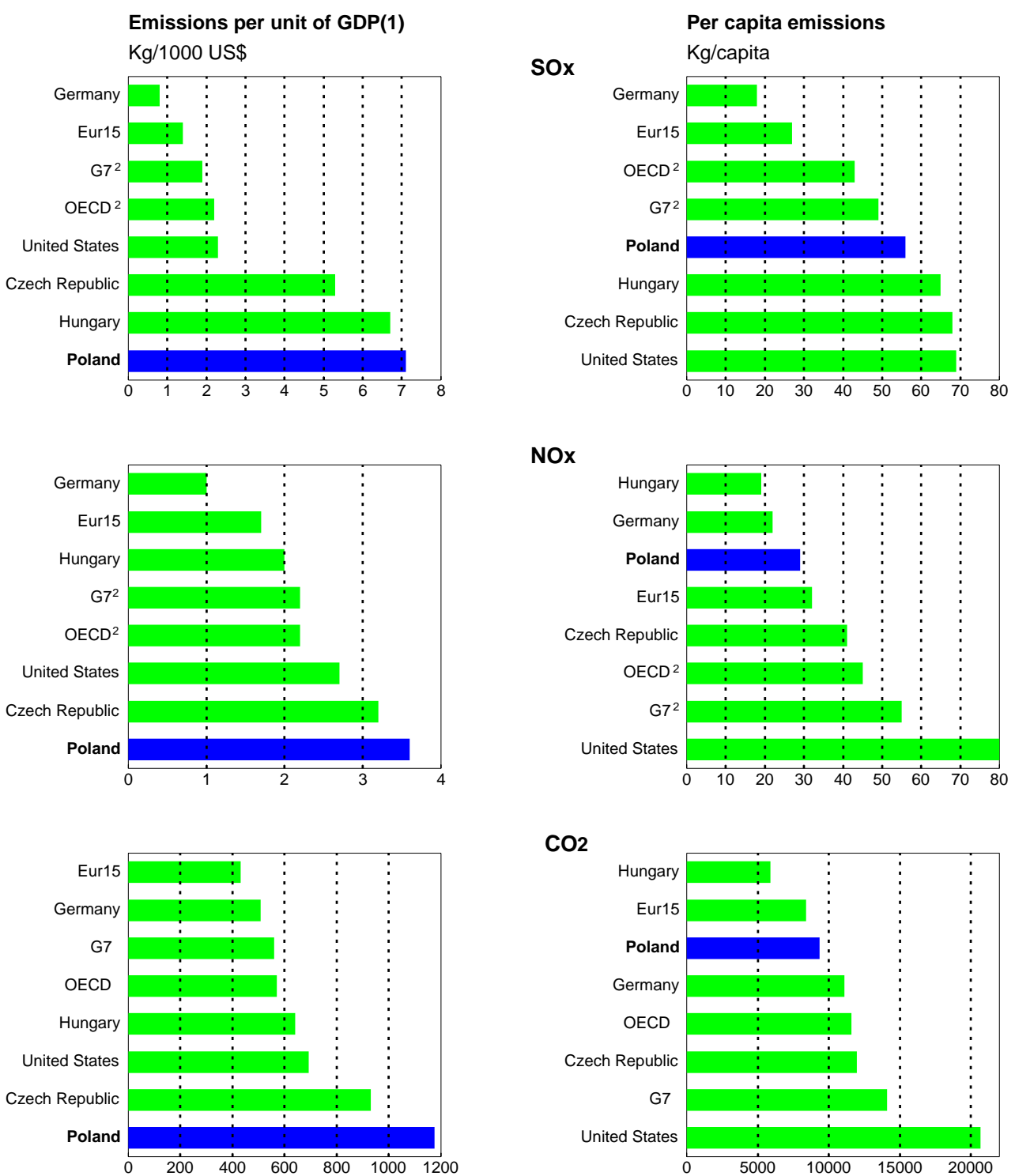

1. GDP at 1995 prices and purchasing power parities 2. Excluding Japan.

Source: OECD. 
Figure 3. Environmental investment expenditure

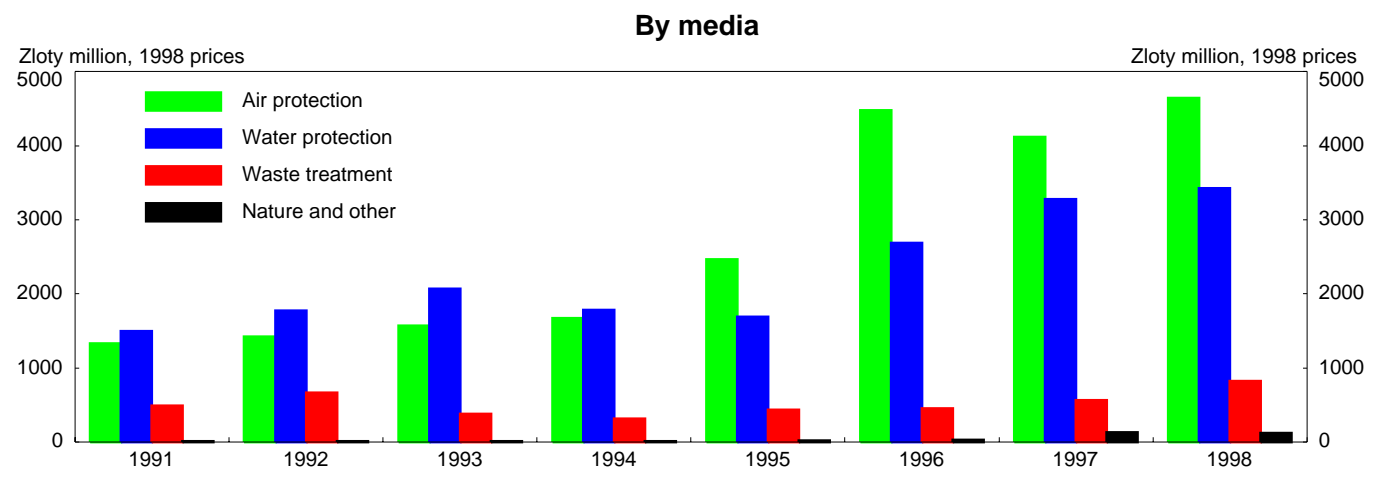

By sources of financing

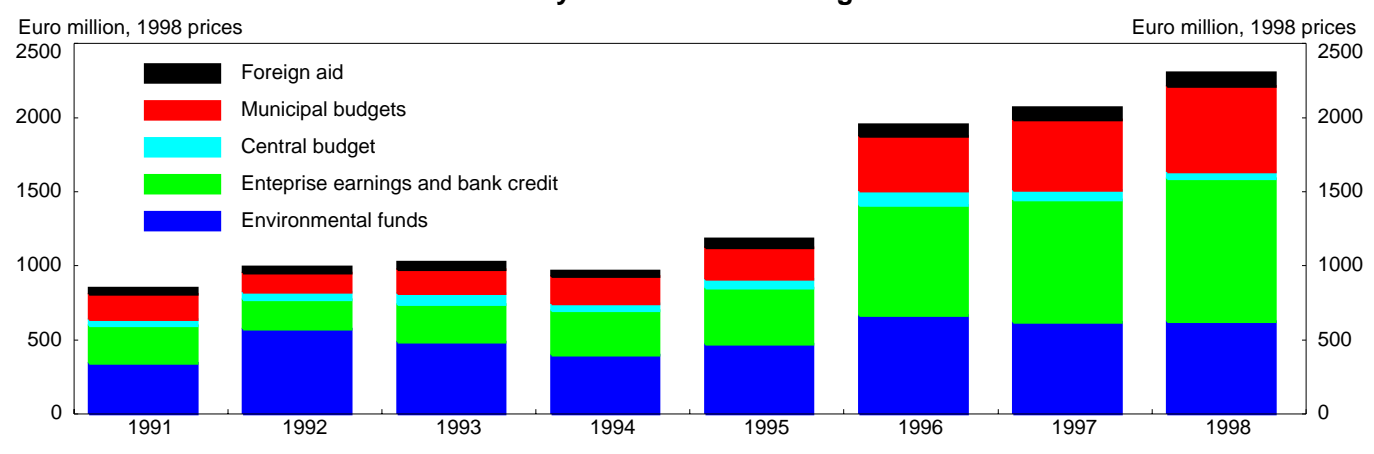

Source: Central Statistical Office.

6. To some extent, these efforts have been fruitful. The pressures typical of the previous regime -- inefficient use of energy, obsolete technologies, disregard of environmental protection -- have been somewhat alleviated. Old industries have been reduced in size, cleaner new industries have been established and environmental policy has led to large scale pollution-reducing investments. Thus, when the OECD first looked at Poland's environmental policy (OECD, 1995a), it found that a commendable framework had been put in place to deal with the sources of pollution inherited from the past. Nonetheless, despite this early progress, the pressure on the quality of air and water remains heavy.

\section{Quality of air}

7. During the last ten years, efforts have been made to reduce emissions of gases into the atmosphere. The reduction of budgetary subsidies to some of the most polluting industries, together with the shift to market-based prices, have encouraged savings in energy consumption. Environmental policy has also encouraged polluters to make use of "end-of-pipe" pollution-reducing equipment. Hence, although economic growth has been spectacular in the last decade, Poland has been able to reduce its air pollution significantly (Figures 4 and 5). For example, between 1988 and 1998 emission into the air of dust particles 
decreased by 74 per cent, of sulphur compounds by 55 per cent, of nitrogen compounds by 36 per cent and of the main greenhouse gas $\mathrm{CO}_{2}$ by 34 per cent. The bulk of emissions reduction has been achieved in the beginning of the 1990s, in connection with the sharp output decline. In the second half of the 1990s, air emissions have continued to contract, albeit at a slower pace or, as in the case of $\mathrm{CO}_{2}$, have stabilised, notwithstanding vigorous economic growth.

Figure 4. Trends in growth, energy and emissions

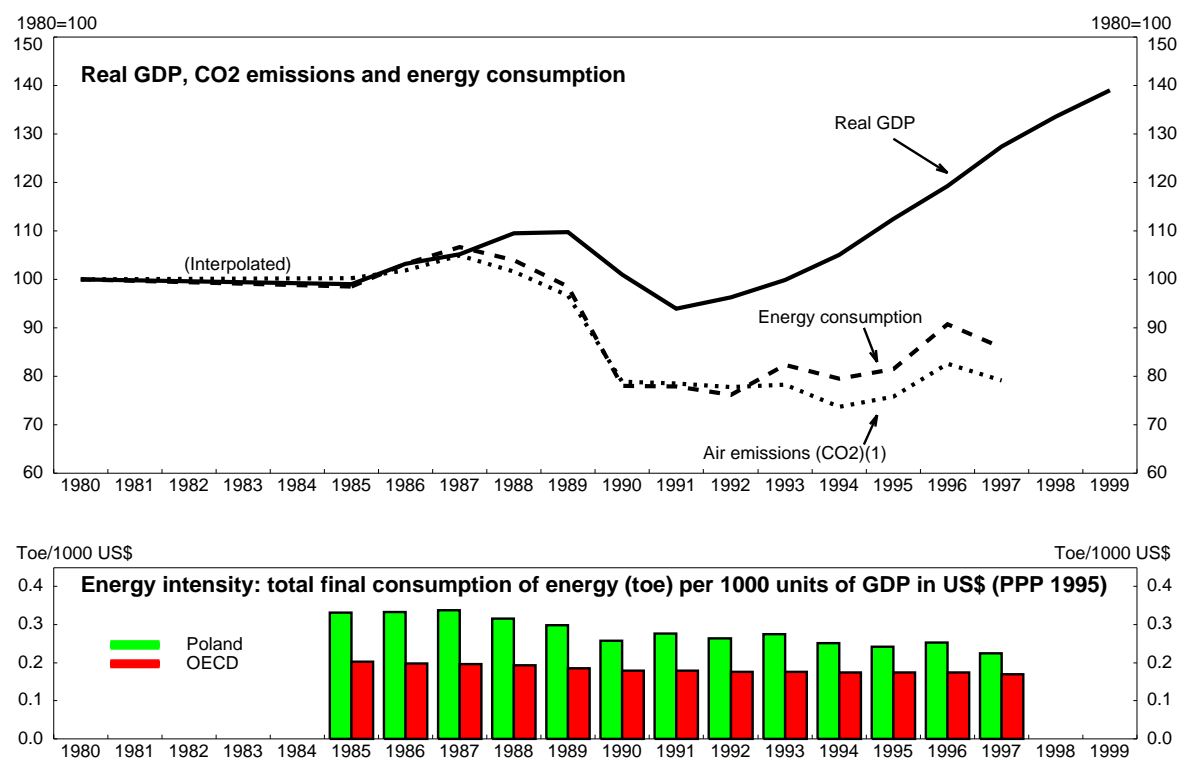

Air emissions and energy consumption by sector, 1997

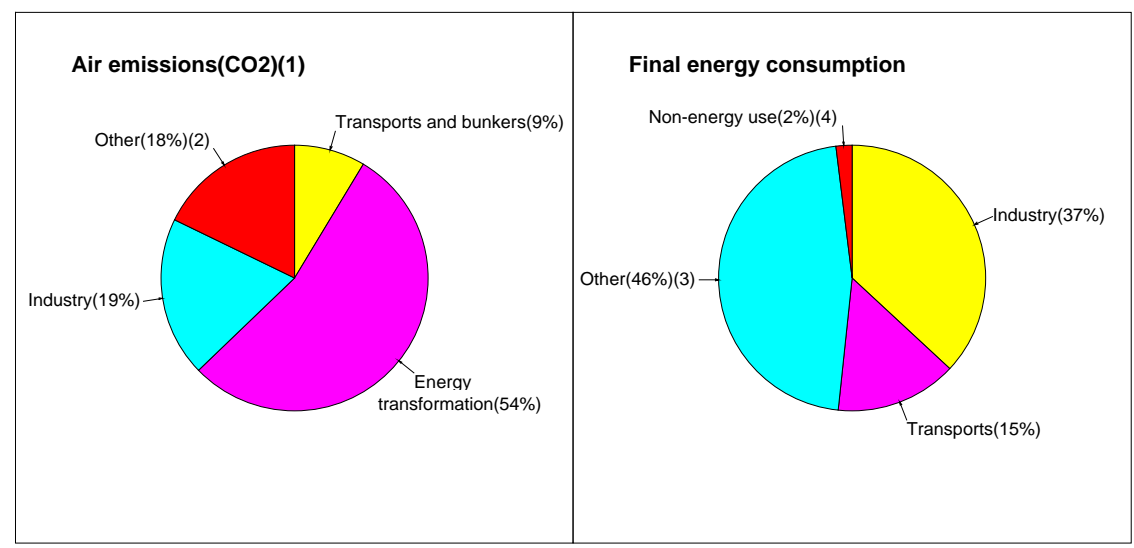

1. From energy use.

. Agriculture, commerce and residential sector.

.

coal by all sectors.

: 
Figure 5. Main pollutants, 1988-98
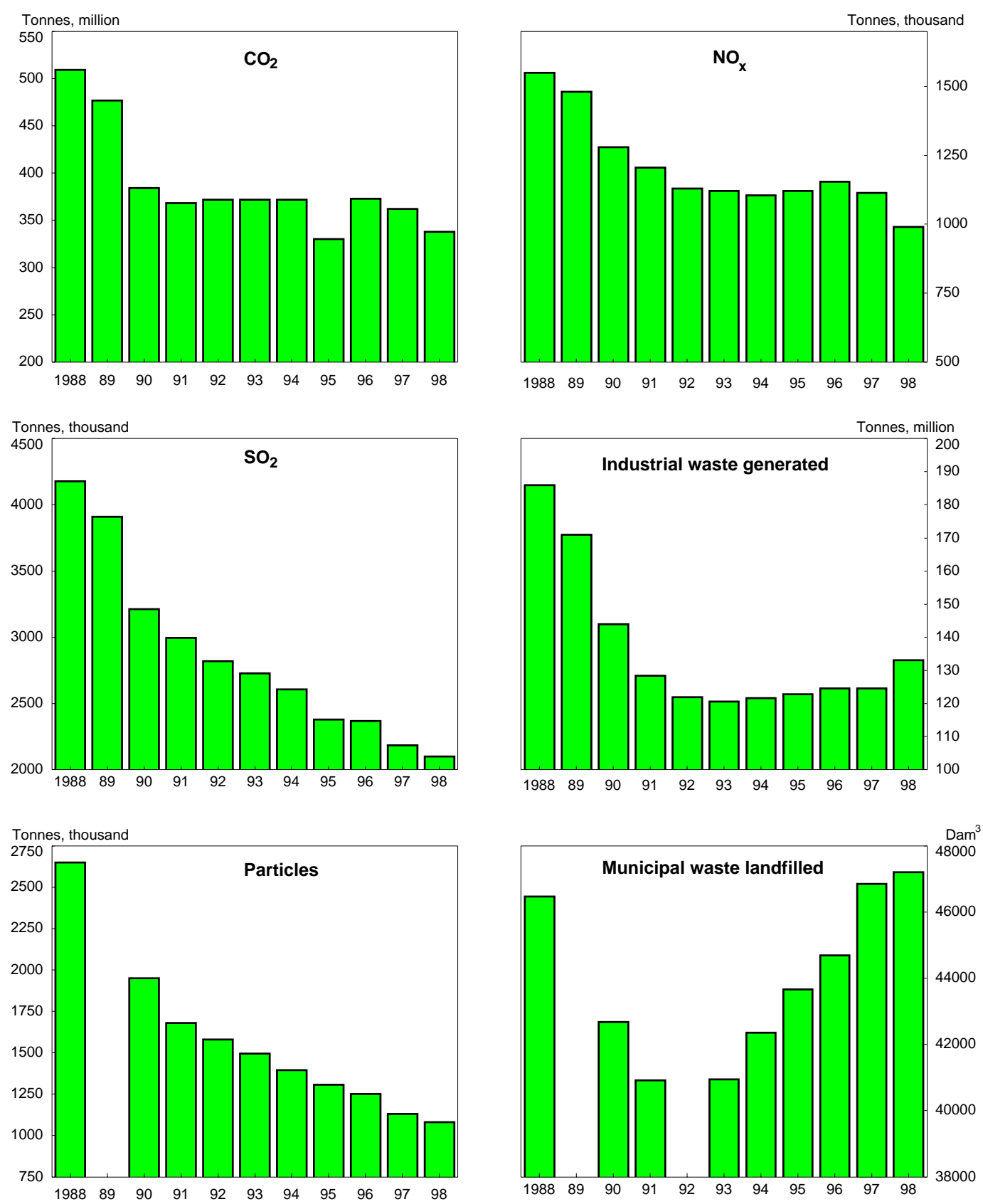

Source: Central Statistical Office, Environmental Protection Yearbook. 
8. Nonetheless, local pollution remains heavy in some cities due to industrial concentration and use of low-quality coal in heating furnaces. For instance, in the Upper-Silesian coal basin, in Walbrzych, Opole and sometimes even in Krakow or Torun, excessive concentration of suspended dust and sulphur are still associated with the winter smog. This constitutes a serious health hazard for the population. The concentration of car traffic in densely-populated areas can also lead to the emergence of pollution "hot spots". Usually $\mathrm{NO}_{\mathrm{x}}$ in urban air does not cause health hazards directly but, together with hydrocarbons, it contributes to the generation of ground level ozone and increasing incidences of so called "summer smog" typical for many OECD urban agglomerations. Thus, acute health hazards associated with ground level ozone are likely to become more common and more severe in large cities.

\section{Quality of water}

9. The extensive use of water for production purposes and the discharge of inadequately treated wastewater into rivers and lakes are major problems for the Polish environment. Following an initial decline, discharges of industrial wastewater have fluctuated since 1993, although the level of treatment also improved. This has led to a decrease in the total load of chemical pollution discharged to surface waters. Coal mines make extensive use of water and release saline waters into rivers imposing significant costs on industries and infrastructure downstream (Ministry of Economy, 1998).

10. Some progress has been made in the last decade to reduce water consumption. Total water withdrawal declined by 21 per cent between 1990 and 1998, thanks to sharp reductions in water needs for irrigation and for communal purposes. In contrast, progress towards improving the biological, physical and chemical quality of surface waters has been uneven (Figure 6). The greatest delays are in the implementation of waste water treatment plants in large agglomerations (Ministry of the Environment, 2000). Only half of the Polish population is connected to a sewage system or a treatment plant, far less than in other OECD countries (Figure 7). For example, Warsaw still discharges 55 per cent of its wastewater directly to the rivers without any treatment (GUS, 2000). Little is done in the agricultural sector to reduce nutrient run-off, although the volumes of fertilisers used in Polish agriculture and the intensity of livestock operations are still several times lower than the OECD average. The discharge of substances into the Baltic Sea significantly increased between 1990 and 1998, with the exception of heavy metals. In particular, increased discharges of nitrogen, phosphorus and phosphates aggravate the threat of eutrophication of the Baltic Sea waters, but this could be attributed primarily to the increased annual precipitation. Relatively high investments in wastewater treatment plants in the 1990s have not led to proportional improvement in quality of surface waters. This suggests that investment resources have not always been targeted at projects that bring the highest environmental benefits. 
Figure 6. Quality of Polish rivers(1)
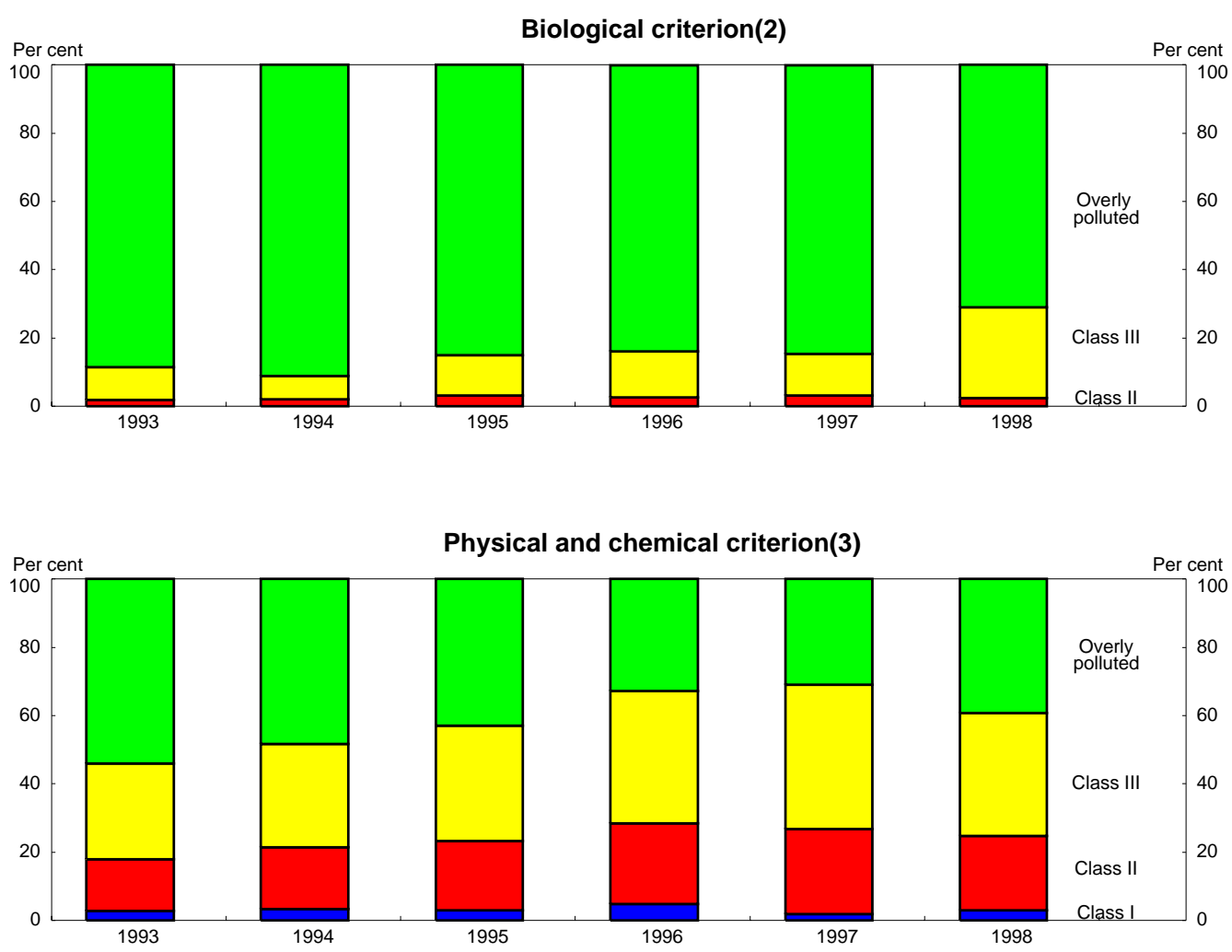

1. The evaluation of water pollution is expressed by designated sections of rivers to individual purity classes. The purity class is established on the basis of the indicator exceeding its standard value to the greatest degree. Class 1 corresponds to waters with the greatest purity.

2. Based on the results of the coli test.

3. Based on surveying 23 physical-chemical properties of water.

Source: Central Statistical Office. 
Figure 7. Water discharge and treatment
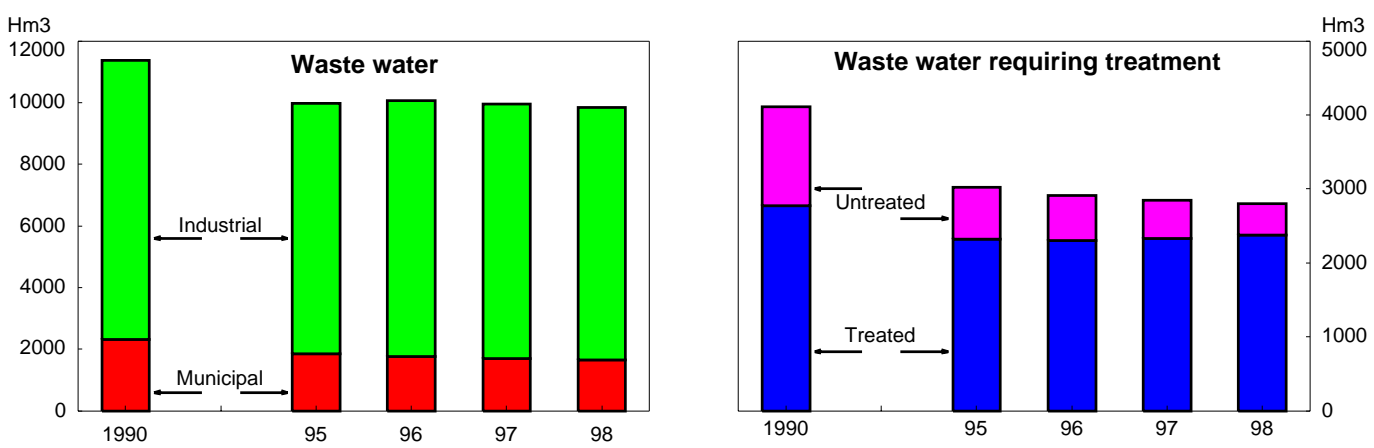

Population connected to sewerage:

Public sewerage

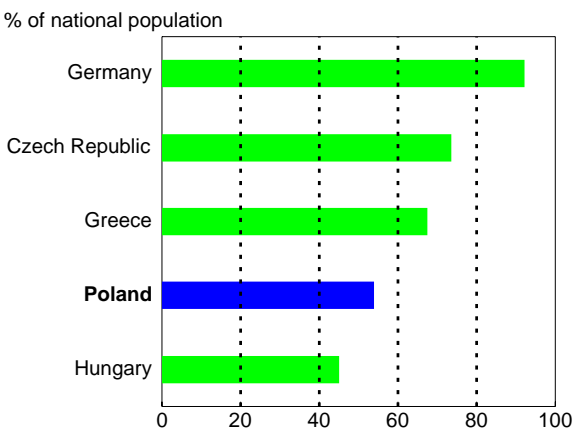

Sewage treatment plant

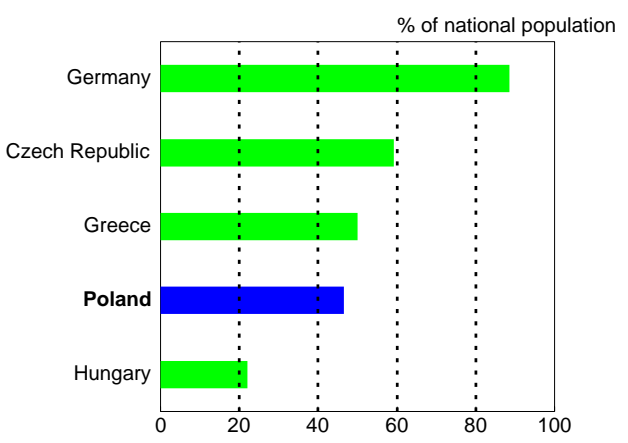

Source: OECD.

\section{Pressures stemming from a fast-growing market economy}

11. In addition to the sources of pollution inherited from the past, the shift to a market economy is generating new types of pressures on the environment. In particular, the number of passenger cars has increased nearly four times in the 1990s. Fortunately cars have become cleaner and the emissions of car fumes (in particular lead, soot and $\mathrm{NO}_{\mathrm{x}}$ ) have not increased commensurately (Figure 8). But the concentration of cars has nevertheless deteriorated the quality of air in inner cities, produced more noise and required new roads, sometimes in well-preserved natural areas. The use of packaging materials, modest in previous times, is growing, and agricultural production will increasingly rely on pesticides and chemicals. A sound framework for sustainable development is thus very much on the agenda for the future. 
Figure 8. Passenger cars and NOx emissions

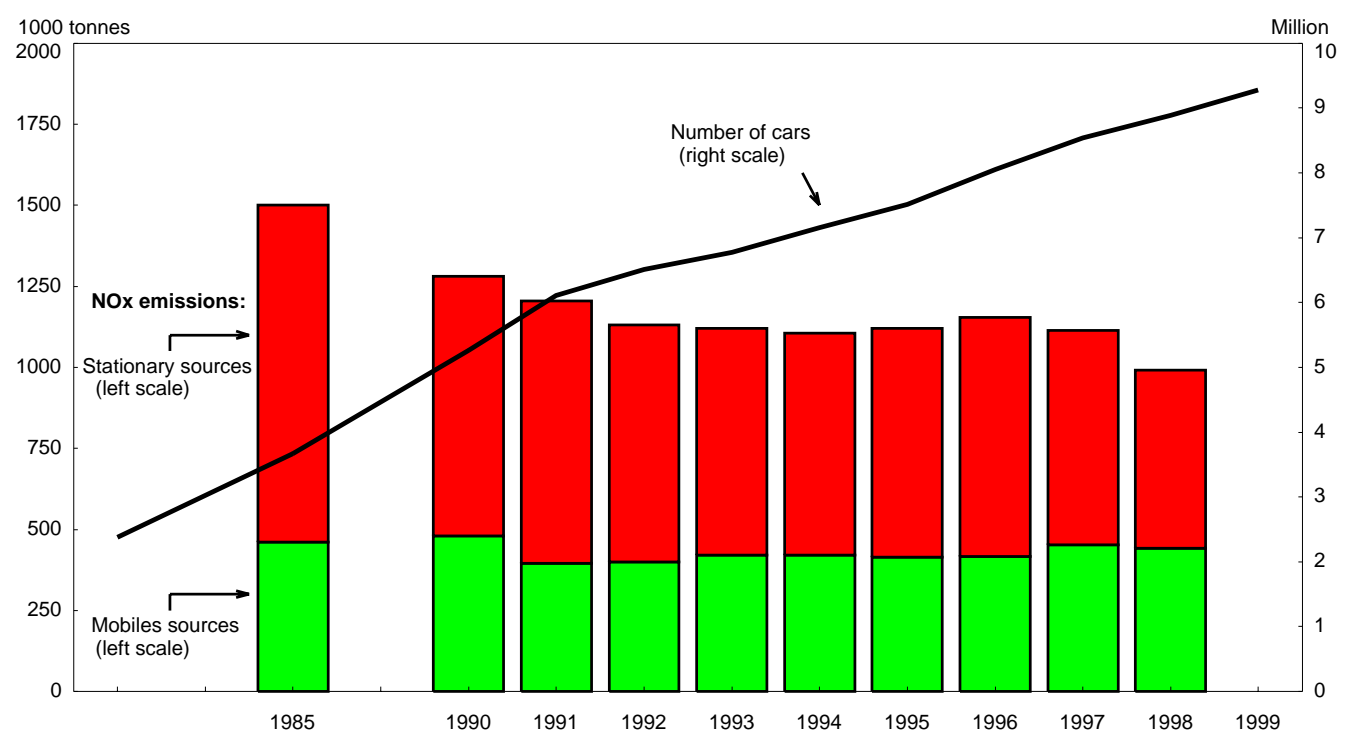

Source: OECD, OECD Environmental data, compendium 1999.

\section{Setting up institutions supportive of sustainable development ${ }^{6}$}

12. Faced with a heavy legacy from the past, Polish governments have endeavoured to strengthen their environmental policy framework. Already in the early-1980s, reforms were introduced to adapt the environmental institutions and instruments. Government agencies have been created to deal with ecological issues at the national and sub-national levels. An environmental inspectorate has been established to ensure an effective implementation of environmental protection law. The reform process has gained a new impetus at the turn of the decade. Existing institutions were strengthened, and new financial mechanisms were set up to foster investment. A bulk of environmental policy responsibilities, in particular for environmental infrastructure, was devolved from Warsaw to locally elected government bodies. The multiplication of public actors has however increased the risk of duplication of functions and dilution of responsibilities. The challenge is to ensure concerted actions of various public bodies and to better integrate environmental objectives in overall government policies.

6. Assistance provided by Environmental Lobbying Support Office (http://www.most.org.pl/bwle) in facilitating access to numerous documents and analytical papers is gratefully acknowledged. 


\section{Numerous environmental policymakers}

13. The present institutional framework is composed of policy-making bodies at the central level and numerous decentralised agencies at the sub-national level (Box 1). The Ministry of the Environment plays a prominent policy-making role: it drafts environmental laws, adjusts the regulatory framework and adapts policy instruments to evolving circumstances. For instance, the Ministry determines environmental quality standards that are binding in the whole country, and establishes environmental technical and product standards. A great deal of responsibility is devolved to regional state administrations and to locally-elected governments. For instance, the authority to issue emission permits is devolved to the Poviat ${ }^{7}$ chief executives (starosta) and to the heads of the Voivodship administrations (Voivod). The Voivodship Environmental Inspectors are in charge of enforcing regulations related to emissions permits and environmental quality standards.

14. Currently environment agencies are well developed and rooted in a two-decade long tradition. The devolution of environmental management responsibilities to sub-national governments is consistent with the "subsidiarity principle" common among OECD countries. In most cases the decisions are taken on a "right" level, i.e. the level at which environmental effects are internalised. However, the division of responsibilities between many agencies with overlapping powers at the central and local levels runs the risk that no one feels accountable for achieving policy objectives. For instance, locally-elected voivodship authorities formulate regional environmental policies but have few instruments to implement them. On the other hand, emission permits for the most hazardous polluters are issued by the centrally-appointed Voivod Governors, who have no responsibility for the formulation and implementation of regional policy objectives and strategies. Probably the most profound institutional friction occurs in the area of water management. Protection of water resources and of quality of drinking water is the task of seven river basin agencies, while water permitting, investment programmes and financial instruments are managed within administrative borders. Such incompatibilities in the institutional framework impede the coherency and evolution of regional environmental policies. Each agency focuses on its own prerogatives, but no institution is interested in the formulation of specific targets related to the quality of water air and soil, and clearly responsible for actual achievement.

\section{The need for policy integration}

15. In addition to proper co-ordination between agencies, environmentally sustainable development also requires to integrate environmental objectives with horizontal (social, economic, fiscal) and sectoral policies. Considerable efforts have been launched recently to introduce environmental requirements into sectoral policies and strategies, with uneven degrees of success, especially in transport (Box 2). The challenge will be to review the weaknesses of these efforts and prepare for their effective implementation. Fewer efforts have been undertaken to integrate environmental issues into horizontal government policies, which is a more difficult task and one faced by all OECD countries. Some important processes have begun, however, such as the analytical work on sustainable production and consumption patterns carried out by the Ministry of Economy, or active participation of the Ministry of the Environment in the preparation of the government strategy for SMEs. A Committee of the Council of Ministers for Regional Policy and Sustainable Development was established in 1998, although with respect to environmental sustainability its role remains very limited. The failure to more strongly integrate environmental objectives into sectoral

7. Poland has four-tier and two types administrative structure. Central, Voivodship (Provicial), Poviat (County), and Gmina (municipality). The first two are centrally elected. The last two are elected locally. At the Voivodship level centrally appointed administration coexist with locally-elected legislature and executive. 
policies frequently stems from the concern that high standards for the environment are costly for the business sector and can be harmful to international competitiveness. These fears are often exaggerated, however. Empirical data show that countries with low environmental standards are not necessarily more competitive (OECD, 1998). Moreover, emissions intensity of industrial production in other OECD countries is typically lower than in Poland, indicating that environmental externalities among main Polish trading partners are better internalised.

\section{Box 1. Key government environmental institutions and their main responsibilities}

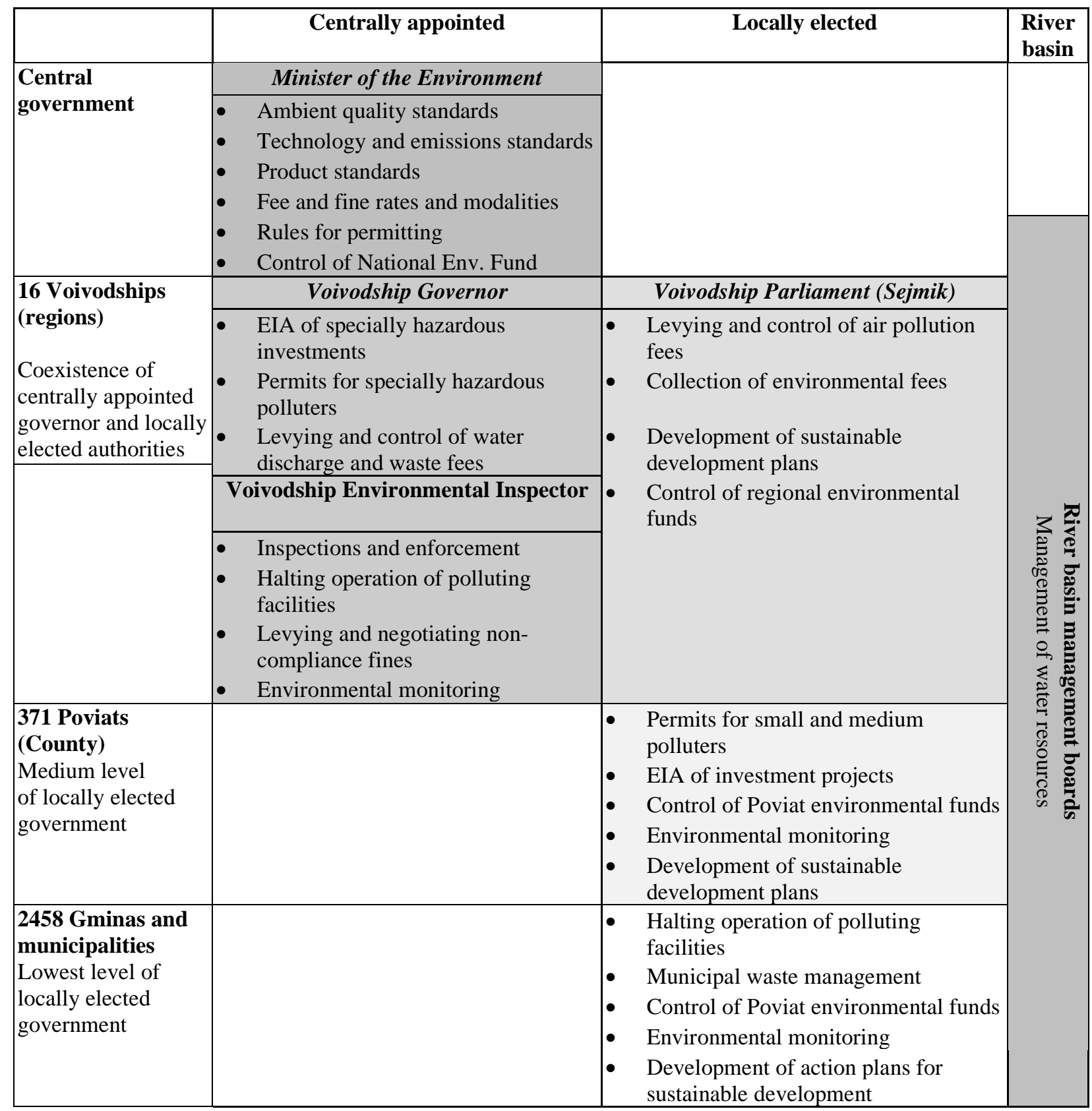




\section{Box 2. Attempts to integrate environmental objectives into other policies: failures and successes}

Several attempts have been made in Poland to integrate environmental concerns into various sectoral policies. Only a few of these attempts have been successful.

Coal sector. The government's Programme in the Coal Mining Sector for the Years 1998-2002 includes an attempt to integrate environmental concerns into the restructuring strategy of the coal mining sector. The programme incorporates the target of removing salt before discharging water and decreasing the amount of waste stored on the surface. It also integrates a timetable for the payment of arrears on emission fees and fines and envisages to liquidate those mines that are unable to meet environment protection requirements. However, these targets have largely remained unfulfilled. An environmental assessment study of the hard coal sector conducted a year after the programme was launched concluded that the sector had not yet developed a coherent environmental management system. Business plans prepared by individual mines and coal companies were found to be ambiguous as regards their environmental components, with neither quantitative targets, nor specific measures or expected effects (Ministry of Economy and Ministry of the State Treasury, 2000).

Steel and iron sector. In the same vein, the Restructuring Programme for the Polish Steel Industry adopted in 1998 makes an attempt to include environmental objectives among other economic, financial and social priorities. The programme makes explicit reference to the need to reduce emissions into the air, and corresponding investments have been authorised. Environmental targets, however, are not specified, apart from the general reference to the need to comply with EU standards. In addition, the document proposes new subsidies to the steel industry for environmental investments, in violation of the Polluter Pays Principle. It also proposes that emission charges paid by steel mills be directly re-invested into the sector, which would adversely affect economic efficiency of allocation of abatement investments and prevent introduction of environmental taxes.

Energy policy. An attempt at integration was also made in the area of energy policy. The Assumptions for the Energy Policy of Poland Until the Year 2020, prepared by the government in February 2000, explicitly incorporates the goal of protecting the natural environment from the emissions of pollutants by the power generation sector. No commitment, however, is made to policies that would include environmental externalities into the energy prices. The document also refers to past and future progress in the development of renewable sources of energy, such as biomass, geothermal resources, hydro-energy and wind. However, the projected share of renewable energies in primary energy production is 5 - 6 per cent in 2020, half of the level recommended by the EU (12 per cent in 2010). In reaction, the Ministry of the Environment has proposed a more aggressive strategy aimed at raising the share of renewable energy sources to 7.5 per cent in 2010 and 14 per cent in 2020. The formulation of these two inconsistent policies on renewable energies illustrates the difficulty of integrating environmental targets in other policies.

Successful attempts. More successful progress has been achieved by the Inter-Ministerial Task Force for the Reform of the Economic Instruments of Environmental Policy. The group consists of officials from the Ministries of the Environment, Finance and Economy, invited experts, as well as representatives of non-governmental organisations and selected business sector organisations. The group was successful, for instance, in mobilising broad support for the introduction of new product charges and deposit fees for selected environmentally harmful products (such as packaging, batteries, fluorescent lamps and tires).

\section{Are the Environment Funds still useful?}

16. Environment Funds were created to provide public financing to environmental projects (Box 3). They comprise the National Fund for Environmental Protection and Water Management (National Fund thereafter), 16 regional Voivodship Funds, over 370 Poviat funds, about 2500 municipal funds and one 
special case, the EcoFund ${ }^{8}$, which manages debt-for-environment swaps. On the national and regional levels they operate as public, independent legal entities, managed by Executive Boards under the oversight of Supervisory Councils, but with government-appointed managers and councils' members. Regional Environment Funds are the instruments of the locally elected administration at the Voivodship level. The National Fund is controlled by the Minister of the Environment. Historically, Environment Funds have played a key role in financing environmental investments, although their share has been gradually shrinking from about 50 per cent in 1992 to less than 30 per cent in 1999. They provide grants, soft loans and take equity stakes to finance a broad range of environmental projects. In addition to a fraction of pollution fees and non-compliance fines, the National Fund and the regional Funds dispose of other resources, such as foreign assistance and earnings from their own financial operations. The National Fund receives about one-quarter of pollution fees, the remainder being split between funds at the voivodship, poviat and gmina levels.

\section{Box 3. Environment Funds in "advanced " OECD countries versus Polish Environment Funds}

There is no exact equivalent to the Polish Environment Funds in "advanced" OECD countries. Some institutions in these countries have similar characteristics, although they are not comprehensive, but rather sector specific, with targeted mandates (e.g. the French or Dutch water agencies or the Superfund in the United States). They are also set up for a strictly limited time. For example the French agencies, managing revenues from air pollution and noise fees, were phased out before 2000. The governments of Austria and Germany are contracting development banks to manage soft-loan programmes in support of municipal environmental infrastructure investments. These programmes are financed through discretionary budgetary transfers. In contrast, Polish Environment Funds have a comprehensive character, without precisely defined objectives or mandates. The range of eligible environmental projects is very wide covering all possible measures in some way related to environmental protection. Funds are not targeted at precisely defined beneficiaries. Neither the time frame for their operations nor conditions for phasing-out are defined in the legal or policy documents. Project selection criteria and maximum rates of assistance are not defined in laws or regulations (except that they fall under recently passed law on state aid, which established maximum rates of state assistance). With the exception of a few regional funds and the Ecofund, most other funds often do not even collect the data required for sound project appraisal. Funds usually support projects irrespective of their financial viability, including projects that would have been financed and implemented anyway. Most funds do not even appraise the commercial viability of projects.

17. The operations of Environment Funds has been debated since the beginning of the transition period. They played an important role in the initial transition period in providing resources at a time when little financing was available from commercial sources. However, the need for official financing of environmental investments is less compelling today. Poland has commercial institutions that can offer financial products well suited to viable investments (including those undertaken by municipalities and utilities), even if projects have modest rates of return. Environment Funds therefore find themselves increasingly competing with private sector financiers, crowding them out of the environmental investment market, which could bring long-term damage to the sustainability of environmental finance.

8. The EcoFund is a unique environmental finance institution in Poland, which was established in 1992 by the Minister of Finance as an independent foundation for the purposes of the management of funds obtained through the conversion of a part of the Polish foreign debt into environmental investments. The finance committed to be spent in the period 1992-2010 amounts to $\$ 545$ million. The EcoFund is managed by an operationally independent Management Board under the supervision of a Foundation Council. The EcoFund offers matching grants (maximum rate of assistance of 30 per cent) for five clearly specified types of projects, mainly of global and cross-boundary significance. The OECD and the EU have conducted an in-depth performance review of EcoFund in 1996. International auditors have highly appraised its compliance with St. Petersburg Guidelines and concluded that EcoFund could serve as a model for public financing institutions in a region. 
18. In addition, there are acknowledged shortcomings in the practices of Environment Funds, such as lack of transparent and rigorous project selection criteria; absence of strategic objectives; and lack of accountability and, sometimes, vulnerability to a capture by different groups of interest. The St-Petersburg guidelines (OECD, 1995b) provide a list of criteria that should be adopted as "good practices", but few Environment Funds have adopted them. The recent analysis of the cost-effectiveness of the project portfolio of the National Fund demonstrated that cost-effectiveness was de facto an irrelevant criterion in selection of projects. Several projects were found excessively costly (Warsaw University, 2000). Most environmental protection projects could today be implemented either without subsidies or with significantly smaller public support if adequate incentives and instruments were in place. Limited public support could then be focused on those projects, which are economically efficient but financially truly nonviable because of externalities involved or public good features.

\section{The mix of environmental policy instruments}

19. Over the last twenty years, Poland has broadened and diversified the mix of instruments used in environmental policy. As in other OECD countries, environmental policy relies primarily on administrative requirements of the command-and-control type. However, contrary to the trends prevailing in the rest of the OECD, there is no tendency in Poland to incorporate economic aspects into the instrument mix. The debates on reforming policy instruments are driven by legalistic arguments related to EU accession or by the lobbying of the strongest interest groups in industry or in administration. Efficiency or costeffectiveness considerations, if heard, are not considered seriously.

\section{“Command and control” instruments}

20. Emissions permits are required to discharge polluted water, emit pollutants in the air and dump waste. Polluters violating the conditions set in their permits must pay non-compliance fines, which are set at a multiple of regular emissions fees (usually 10 times) and are paid from after-tax income. Only 1520 per cent of fines is collected, however, as environmental inspectors can defer and eventually offset fines against polluters' investments made to improve compliance. In extreme cases Voivodship Environment State Inspectors have the right to close discharging installations operating without or drastically violating permits. The air pollution permits set source-specific emissions ceilings in order to prevent excessive concentration of pollutants in ambient air. Permits are required separately for each source of pollutionthat is, a plant needs separate permits for water, air and waste. As part of the transposition of the EU directive on integrated pollution prevention and control (IPPC), the new draft Law on Environmental Protection, pending in Parliament, introduces "integrated permits" for large polluters. Integrated permits will cover all direct and indirect discharges to any medium (air, water and soil), as well as issues such as waste minimisation, energy efficiency, resource utilisation, prevention of accidents and the restoration of sites after the industrial activity has ceased. Instead of existing ambient quality standards, the benchmark for new permitting system will be the technology-oriented standards following the "Best Available Technique (BAT)" approach".

21. As part of its transposition of the EU legislation, Poland will have to adapt its environmental policy instruments to, inter alia, the Integrated Pollution Prevention and Control (IPCC) Directive. IPPC

9. Under the BAT approach, experts from the European Commission determine what is thought to be the best technique for reducing a particular type of emission in a given production process. The word "technique" is used rather than the word "technology" to indicate that the regulation encompasses the role of management and operating practices, together with the choice of technologies. Installation of equipment is not considered sufficient; good management practices are also required. 
applies to six sectors of activity: energy, production and processing of metals, minerals, waste management, and "other industries"10. The Directive mandates using BAT (best available technique) as a reference for abatement requirements. The experience with technology based standards, such as BAT, has been mixed in OECD countries. On the positive side, BAT-based standards are transparent and relatively easy to monitor and enforce. On the negative, they are not cost-effective, because they imply application of similar technical solutions and similar level of abatement by all polluters, irrespective of their marginal abatement costs. They may discourage innovation and be abused as trade barriers. They may also distort competition by locking firms in technologies that their competitors have developed and registered with authorities as BAT. Permits based on BAT narrow the room for using cost-effective approaches to pollution reduction, such as economic instruments (see Box 4). They also do not guarantee that desired quality of environment will be achieved.

22. Another instrument that has contributed to higher compliance with permits is the publication by Environmental Inspectorates of lists of the worst polluters. The lists help focus scarce resources of enforcement agencies and the attention of environmental non-government organisations on critical sources of pollution. The list of the top 80 worst national polluters has gained influence in the last decade, when these firms found themselves under competitive pressure. Difficulties in attracting (especially foreign) investors and even raising commercial debt has prompted many of them to accelerate environmental performance efforts and attain compliance with environmental permits. At the end of 1999, already 31 of the formerly worst polluters had been removed from the list.

\section{Box 4. Mixing economic instruments and technology standards}

Economic instruments can be quite easily mixed with a permitting system that uses emission ceilings determined by reference to environmental quality standards. Blending economic instruments with permits that are determined by reference to specific technologies is more problematic. For example, if there is a regional concentration of plants, each complying with BAT standards, their combined pollution may still exceed the environmental quality standards. The IPPC Directive stipulates that if this happens, additional measures (e.g. marketbased economic instruments) need to be taken by the authorities to achieve environmental quality objectives. In principle, it is therefore possible to combine BAT-based permits (both integrated and traditional) to meet "core" IPPC requirements with other instruments in order to attain ambient quality objectives. Such combined approach is actually used in the British regulatory framework for the power sector (Klassen, 1996) and in the US acid rain programme (McLean, 1996) and has been proposed for the Polish power sector by Fiedor et al. (2000). But the real question is whether it makes sense to apply economic instruments for the sake of principle. The use of economic instruments brings value added only if there is room to reduce the overall cost of emission reduction to industry as a whole by taking advantage of differences in marginal abatement costs between individual firms. Under such conditions economic instruments facilitate efficient emission reduction programme from the industry, by allocating major abatement efforts to those polluters, who can do it at the least cost. However, if all firms apply similar technologies in order to comply with BAT, the differences in marginal abatement costs among them become negligible. Under such conditions there are few reasons to apply economic instruments on top of BAT standards to achieve additional emissions reduction. This raises a fundamental question -- why not apply economic instruments from the outset and achieve exactly the same environmental effect while fully utilising the potential of economic instruments to minimise the costs of emissions reduction?

10. The "other industry" category comprises paper and pulp production, textile treatment, tanning, food processing, and intensive livestock operations. 


\section{Market-based instruments}

23. An ambitious system of emission fees was first introduced in 1980. Fees are currently imposed on the use of water, disposal and landfilling of waste, emissions of pollutants into the air and exploitation of natural resources ${ }^{11}$. A total of 62 air pollutants are subject to fees. Pollution fees serve two purposes. First, they raise revenues that are earmarked to Environment Funds. Second, they are used to send price signals on the true cost of using the environment, and therefore stimulate improvement in environmental performance.

24. The pollution fee system has fulfilled reasonably well this first revenue-raising function. In 1999, the fees generated revenue of $\mathrm{Zl} 1.6$ billion ( 0.26 per cent of GDP and 1.3 per cent of state tax revenue). Collection rates are high, reaching well over 90 per cent (closer to 100 per cent outside of the coal mining sector). Important elements of this successful collection include a good design of the system, a decade long experience and familiarity with its operation and a strict elimination of discretion on the side of administration. Like for tax liabilities, the authorities are not allowed to negotiate the volumes or schedules of payments with polluters. Forgiveness and offsets of pollution charges are also strictly prohibited.

25. The fees fulfil their second function - sending adequate price signals - much less effectively. Polish pollution fees are high if compared with countries that use them for revenue raising purposes (France, United States, Japan, Netherlands), but they are several times lower than emissions fees and taxes designed for incentive purposes, such as in Sweden $\left(\mathrm{SO}_{2}, \mathrm{CO}_{2}\right)$, Norway $\left(\mathrm{CO}_{2}\right)$, Germany, Slovenia and Czech Republic (water effluents). Indeed, the rates of Polish pollution fees are established on the basis of criteria unrelated to the abatement costs, implying that de facto, they are not designed with incentive effects in mind (Box 5). The fee rates for air emissions remain in the low range of marginal abatement costs, indicating that they provide some incentive to reduce emissions, but not enough to achieve emission reduction targets needed for EU accession (Box 6).

\section{Box 5. Are water discharge fees too low?}

Wastewater discharge fees paid by commercial enterprises are high enough to provide strong incentive to treat sewerage. In contrast, the fees applied to municipalities and water utilities are only one-fifth of those paid by enterprises, and therefore provide no such incentive. This is clearly illustrated by Figure 9. If the same fee rate was applied to households and industries, it would provide sufficient incentive to treat wastewater even in small municipalities, where unit treatment costs are very high. The current scheme also involves cross-subsidisation of municipalities by industry, which runs counter to the Polluter Pays Principle. In contrast to Poland, very high wastewater charges are imposed on municipalities in Slovenia and the Czech Republic, as part of their implementation programme of the EU Urban Wastewater Directive. It is unlikely that Poland will be able to develop the municipal wastewater infrastructure needed for EU accession if the current fee structure is maintained. A similar problem of perverse incentives affects water abstraction fees (Figure 9).

(continued on next page)

11. Krakow University of Economics (1999) and Klarer, J., J. McNicholas, E. Knaus (1999), Sourcebook on Economic Instruments for Environmental Policy in Central and Eastern Europe. A Regional Analysis, REC, Szentendre, Hungary. 
Figure 9. Wastewater effluent fees and treatment cost

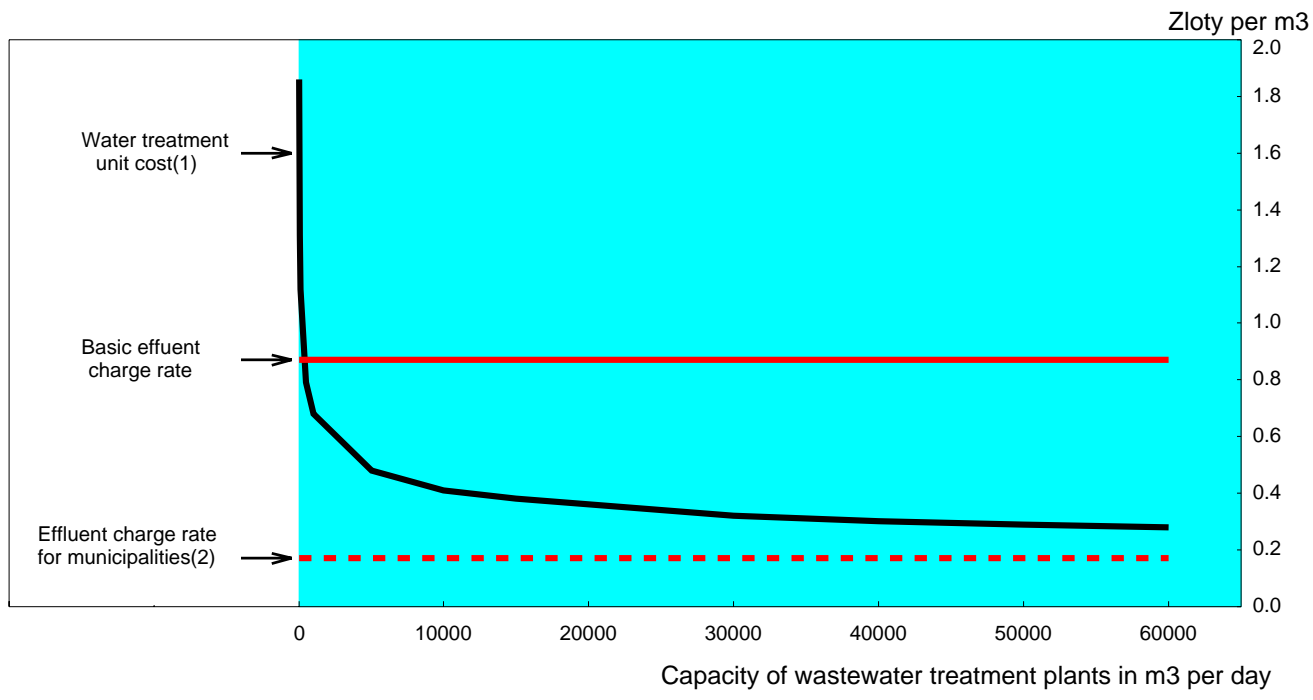

1. Operation and maintenance of water treatment plants plus depreciation cost.

2. Basic rate multiplied by 0.2 .

charges for the Special Utilisation of Water and Water Facilities. Study for the Ministry of Environment.

26. Left unchanged, the revenue-raising function of the emission fees is doomed to dwindle, as progress is being made to reduce pollution. The total revenues from fees and fines already declined from Z1 2 billion in 1998 to Zl 1.6 billion in 1999. In addition, the present high collection rate could decline if provisions included in the draft framework Environmental Protection Act were adopted. These provisions open the door for administrative discretion and individual negotiations concerning the payment of pollution fees. This could reduce the collection rate of fees to an estimated 15-20 per cent (similar to that of noncompliance fines) and may threaten an interesting and relatively successful system. Hence, a new approach is needed to clarify the objectives of the emission fee system. Reform is also needed because the air emissions fee system seems excessively complicated - there are more fees than the government can reasonably monitor. Significant reduction in the number of air emission fees would reduce the transaction costs for firms and the administration without doing much harm to revenue flows and to the environment. ${ }^{12}$

12. The first step towards reform has been taken. With the draft "Law on responsibilities of producers and on product charges", environmental surcharges on selected products and deposit-refund schemes are proposed. They are expected to substitute for the expected decline of the revenue generated by emissions fees. 


\section{Box 6. Have air emission charges in Poland encouraged emissions reduction?}

Figure 10 shows that by 1996 already more than half of the original $\mathrm{SO}_{2}$ emissions of power plants had been abated, most of which was achieved at low marginal costs (about $€ 0.40 / \mathrm{kg}$ ). However, in some cases "expensive" technologies were also applied with the maximum marginal cost of $€ 1.1 / \mathrm{kg}$. Additional reduction of $\mathrm{SO}_{2}$ emissions achieved in the period 1996-2000 is estimated at about $370 \mathrm{kton}$. Marginal costs of these abatement efforts were in general little higher than for the "1996 reductions". After 2000 there is still the option to reduce about 325 kton of $\mathrm{SO}_{2}$-emissions. The potential to achieve this further abatement with inexpensive technologies still exists, but is limited as the graph shows. The marginal costs of these reductions are expected to be higher than in any period in the past.

Figure 10. Incentive effect of fees on power sector SO2 emissions

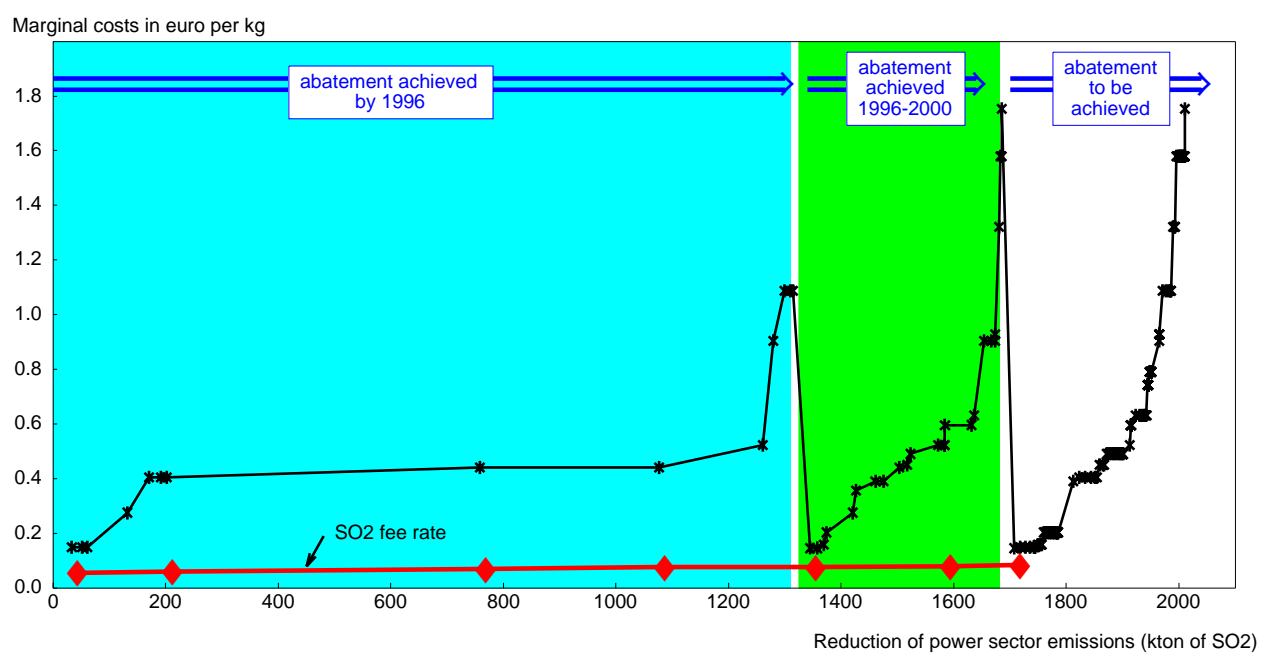

Note : The graph refers to three subsequent periods and, for each period, the emission reductions are sorted out by the marginal costs of different abatement technologies, and not in chronological order.

Source: Jochem Jantzen (2001), TME, Marginal costs of SO2-emission reduction, Poland, and Ministry of Environment.

During the 1990s, the rates of $\mathrm{SO}_{2}$ emissions charges were in the range $€ 0.07-0.09 / \mathrm{kg}$ and therefore did not provide significant incentives to reduce $\mathrm{SO}_{2}$ emissions in the power sector. Actually not a single abatement technology could have been applied because of the incentive effect of $\mathrm{SO}_{2}$ charge alone. A bulk of abatement effort in this sector could be attributed to the application of other environmental policy instruments (permits, subsidies, public lists of the worst polluters, etc.) and to the "environmental dividend" of market reforms. In order to achieve further reduction of $\mathrm{SO}_{2}$ emissions in the power sector by 50 per cent from the 2000 levels using the pollution charge as a sole instrument the rate should increase from the present $€ 85$ /tonne to about $€ 400$ per tonne. The emissions reduction by 75 per cent would require the rate to increase up to about $€ 630$ /tonne. These estimates are for illustrative purposes only. The exact rate of an incentive charge would need to take into account the aggregated burden of different pollution charges (e.g. for $\mathrm{NO}_{\mathrm{x}}$ and $\mathrm{CO}_{2}$ ) and the fact that some abatement technologies reduce several pollutants simultaneously. Careful modelling (e.g. using tools like MOSES ${ }^{1}$ ) and policy analysis would be needed before incentive charges are adopted.

1

MOSES $=$ the Model On Sustainable Environmental Economic Scenario's, an Excel spreadsheet model developed by the Institute for Applied Environmental Economics, the Hague (www.tme.nu) where more information on MOSES can be obtained. 
27. The tax system is increasingly used in OECD countries to provide ecologically-oriented incentives. Poland impose taxes on gasoline, mainly to raise government revenue, but also to encourage energy savings (Figure 11). A significant excise tax is also imposed on the purchase of new passenger cars since 2000 , with an equally positive impact on the environment. On the other hand, some environmentallyharmful commodities are tax-free. For example, coal is not subject to excise taxes, although it is the dirtiest type of fossil fuel. This discourages the switch of power generation plants and heating boilers to cleaner sources of energy, such as natural gas. In other OECD countries, the new green taxes are often introduced in a revenue neutral way, as they replace existing taxes. Thus, the concept of "green tax reform" involves using additional revenue from such taxes to reduce other, distortionary taxes. For instance, the German higher taxes on energy are used to lower social security contributions. Similar approach in Poland could foster job creation.

Figure 11. Premium unleaded gasoline price

In US dollars per litre

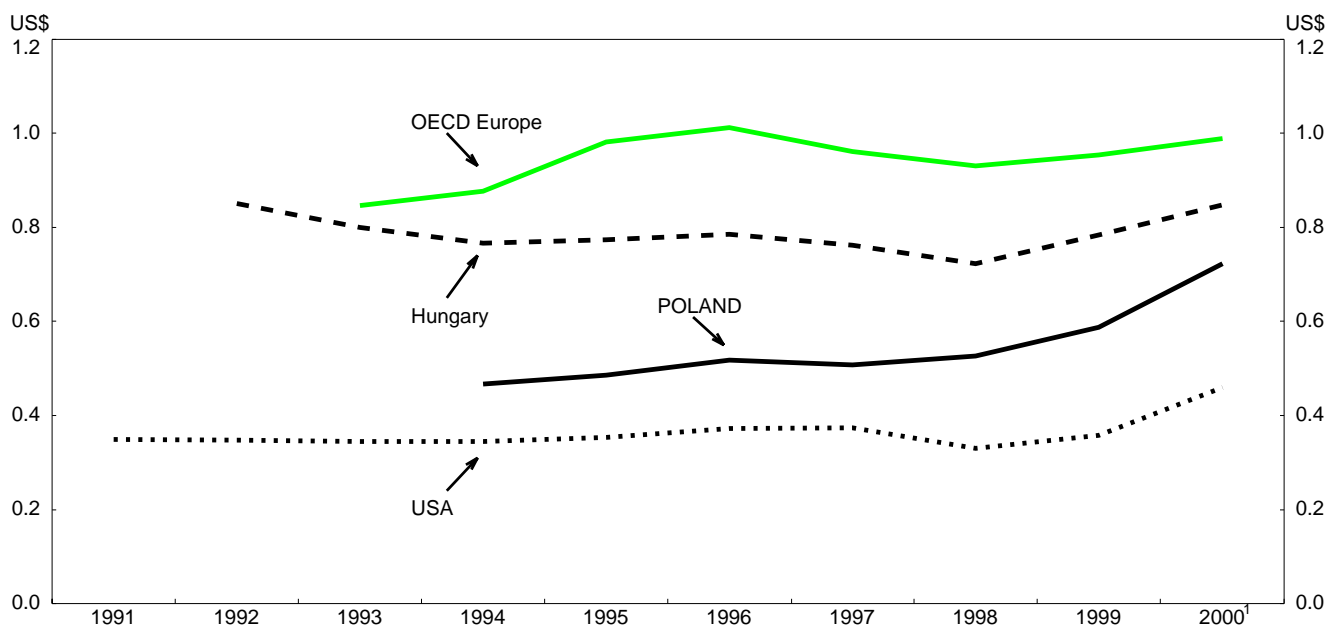

1. Data for 2000 Q2

Source: IEA, Energy prices and taxes.

28. Trading of emission permits is another interesting economic instrument that has been used effectively in some OECD countries. It is an effective way to cap emissions, but also a cost effective one. Emission trading was recommended by the government already in 1991 in the first National Environmental Policy. Since that time, a successful pilot experiment has been implemented in Chorzow, where a significant environmental improvements were accelerated at the very low cost by allowing an indirect exchange of the rights to emit $\mathrm{SO}_{2}$ between the large steel and power plants. A number of studies proved the feasibility of a regional emission bubble (Atmoterm, 1996) and sectoral emission trading (Peszko, 1996; Fiedor et al., 2000). The power sector has called several times for replacing plant specific permits with a sectoral cap and tradable emission quotas for base load power plants to decrease the costs of meeting the emission ceilings required by the international agreements on $\mathrm{SO}_{2}$ and $\mathrm{CO}_{2}$. This notwithstanding, emission trading is still not a priority for the Ministry of Environment and still has not found its way to legislation. 
29. As noted in the 2001 OECD Economic Survey of Poland, the authorities have granted subsidies to various sectors to mitigate the social impact of economic restructuring. Many of these subsidy schemes have a detrimental impact on the environment, and are perverse on efficiency grounds. This is particularly the case of subsidies to the coal extraction and the steel mill sectors, which are among the most polluting activities. Several environmentally perverse subsidies are also used in the agriculture and transport sectors. In addition to general subsidies to loss-making firms, Poland also provides subsidies directly targeted towards pollution abatement. For instance, soft loans and grants are provided to polluters that invest in environmental protection equipment. Most of these subsidies contradict the OECD polluter-pays-principle (Box 7).

\section{Box 7. Subsidies and the Polluter Pays Principle}

The Polluter-Pays-Principle (PPP) as adopted by the OECD implies that polluters should meet the cost of pollution control and prevention measures. In 1991, OECD countries accepted an extension to this original core meaning of PPP, and recognised that pollution damage costs should also be borne by the polluter (OECD, 1992). Nonetheless, the PPP first and foremost implies that polluters should in general not be subsidised, although exceptions to the "no subsidy" philosophy are accepted. Subsidies or soft financing are deemed to be justified exceptionally, and only under specific conditions: subsidies should not introduce significant distortions in international trade and investment; they should be limited to sectors which would otherwise have great difficulty complying with environmental requirements; and they should be limited to a well-defined transition period and adapted to the specific social and economic problems associated with the implementation of a country's environmental policy.

\section{Would voluntary agreements be effective instruments?}

30. At present, little discretion is authorised in the present system of environmental regulations. As signalled, however, the new draft Framework Environmental Law introduces an instrument of "negotiated compliance schedules" for individual firms, a form of voluntary agreement. This is intended to bring flexibility to the hitherto rigid permitting system, but may reduce the willingness to pay emission taxes and create obstacles to introducing emissions trading. An OECD assessment of "voluntary environmental agreements" in the United States, Canada, Japan and some EU countries calls for a very cautious consideration of their use (OECD, 1999). The OECD found that empirical evidence so far only weakly supports the argument of environmental effectiveness, cost-effectiveness and administrative efficiency of voluntary agreements. Agreements negotiated so far often "mandated" firms to undertake measures that they would have done anyway without any external pressures. In addition, voluntary agreements seem to have provided little incentive to innovate. Free-riding and regulatory capture sometimes seriously affected their effectiveness (e.g. OECD, 2000a). Therefore, the OECD recommends that several conditions should be in place in the design of voluntary agreements. One essential condition is a credible regulatory threat if firms just do business-as-usual. This condition is arguably yet to be developed in Poland. Economic instruments offer an effective alternative to voluntary approaches, especially emissions trading - such as the US trading approach to phase out lead used by refineries and $\mathrm{SO}_{2}$ released by combustion plants. These instruments have proven to deliver the benefits that voluntary agreements have so far merely promised (environmental effectiveness, flexibility, cost-effectiveness, administrative efficiency). Hence they could provide an environmentally effective and efficient alternative free from the flaws of the individual negotiations. 


\section{How to undertake the environmental clean-up required by the EU?}

31. Accession to the European Union will impose to bring the national environmental legislation in conformity with the EU laws. The main consequence of this legal approximation is that some environmental standards will become stricter than under Polish previous rules (such as for large combustion plants, landfills or large wastewater treatment plants). Hence, institutional reform and large scale investments will be needed to comply with them.

32. The EU legislation in the environmental field consists of some 460 pieces of legal acts that will have to be directly applied or transposed into the national legal system by the time of accession. The European Commission will also require that the Polish government ensures actual compliance with the requirements contained in this legislation. Implementation of the legal acts must be completed by the dates specified in each legal act. The European Commission has recognised that if implementation involves excessive costs, transition periods can be negotiated (European Commission, 1998). Transition periods, however, are intended to be an exception, rather than a rule. The Commission also requires that requests for transition periods be supported by convincing arguments and credible implementation strategies.

33. Complying with the new body of legislation implies significant investment in the case of about 15 Directives. Of these, 10-11 Directives will involve heavy public investments in infrastructure, such as water, sanitation, heat, power and waste management. A few other directives — such as on integrated pollution prevention and control (IPPC), on discharges of dangerous substances into water, on fuel quality and on nitrates - will impose adjustment costs mainly on the private sector.

34. The order of magnitude of the costs of compliance for Poland is well documented ${ }^{13}$. After being brought up to date, available estimates suggest that the investment expenditures required to comply with current accession requirements concerning the environment amount to $€ 25$ billion under low cost scenarios, but may double in the absence of cost-effective implementation strategies (Table 1). Assuming reasonable transitional periods and cost-effective approaches, the investment expenditure would be $€ 2.1$ billion annually, with a 12-year transition period, and $€ 1.6$ billion with a 15 -year transition period. If less cost-effective approaches were chosen, these sums would jump to $€ 4.3$ billion per year with a 12-year implementation period, and $€ 3.4$ billion with a 15 -year implementation period.

35. Three key factors can contribute to greater cost effectiveness and therefore reduce the overall spending expenditure associated with EU accession. First, spending can be reduced by using the flexibility provisions included in many directives. Directives are legal acts that do not have to be literally re-written into national laws. They need to be "transposed", although the Commission can judge if transposition meets essential requirements and the objectives of directives. For example, urban waste water directive requires to apply stringent standards for the removal of nitrogen and phosphorus from sewerage only if treated waters are discharged to water bodies sensitive to eutrophication. For other waters, lower levels of treatment are considered sufficient. Unfortunately, in the absence of thorough analysis on which water bodies are sensitive, and which are not, the government has considered the whole country to be sensitive.

13. In critical public sectors, such as sanitation, large combustion plants and drinking water, several independent studies were conducted (Krakow University of Economics, Grontmij, 1996; TME, 1999, World Bank, 2000) and results are detailed and relatively robust. In addition detailed studies of costs of compliance with Large Combustion Plant Directive were conducted by EnergySys in 1997 and recently by Energoprojekt in 2000. Estimates of costs of compliance with EU laws on waste management cast more doubts due to the uncertainties on the flows of different types of waste produced in Poland (Berbeka, and Grabowski, 1999). The Directives that will cause adjustment burden to the private sector have been studied the least. In particular, implementation of IPPC Directive can be disruptive and very costly for some industrial sectors, but the cost can be only grossly estimated. 
This is pushing up the total investment expenditure requirement by 25 per cent according to the World Bank compared to a situation where no waters would be sensitive (World Bank, 2000). ${ }^{14}$

Table 1. Investment expenditure required for EU accession in environmental protection In billions of 1998 Euros

\begin{tabular}{ccclc}
\hline Sector & $\begin{array}{c}\text { Low } \\
\text { estimate }\end{array}$ & $\begin{array}{c}\text { High } \\
\text { estimate }\end{array}$ & Notes & Source \\
Waste water treatment plants & 1.6 & $3.6 \quad \begin{array}{l}\text { Low estimate is for towns only. } \\
\text { High estimate includes } \\
\text { Biol/advanced WTPS for all } \\
\text { settlements over 2 000 }\end{array}$ & $\begin{array}{l}\text { TME, 1999 (low), } \\
\text { World Bank 2000 }\end{array}$
\end{tabular}

\begin{tabular}{|c|c|c|c|c|}
\hline Waste water collecting systems & 4.1 & 10.4 & & World Bank 2000 \\
\hline Total for sanitation infrastructure & 6.4 & 14.0 & -- & \\
\hline Drinking water & 3.0 & 8.0 & Rough estimates & World Bank 2000 \\
\hline Long range air & 1.7 & 4.2 & $\begin{array}{l}\text { Low is for compliance with } \\
\text { existing law by existing sources. } \\
\text { High is for compliance with draft } \\
\text { Directive proposed by EC and } \\
\text { includes new sources }\end{array}$ & Energoproject 2000 \\
\hline Urban air & 3.3 & 4.5 & -- & World Bank 2000 \\
\hline IPCC & 6.3 & 6.3 & $\begin{array}{l}\text { Additional expenditure for power } \\
\text { sector only }\end{array}$ & TME 1999 \\
\hline Waste & 2.6 & 4.1 & -- & $\begin{array}{l}\text { TME, 1999; } \\
\text { Berbeka, Grabowski } \\
1999\end{array}$ \\
\hline Nitrates & 2.6 & 3.3 & $\begin{array}{l}\text { High estimate assumes that a } \\
\text { quarter }(500 \text { 000) of all Polish } \\
\text { farms will be liable for a } \\
\text { Directive. Low estimate } \\
\text { assumes that only } 400000 \text { will } \\
\text { be. }\end{array}$ & World Bank 2000 \\
\hline $\begin{array}{l}\text { Total at the time the studies were } \\
\text { conducted }\end{array}$ & 32 & 58 & -- & best estimates \\
\hline $\begin{array}{l}\text { Environmental expenditure 1997- } \\
2000 \text { (billion 1998) }\end{array}$ & 7.0 & 7.0 & -- & $\begin{array}{l}1997-1999 \text { GUS. For } \\
2000 \text { extrapolation by } \\
\text { OECD Secretariat }\end{array}$ \\
\hline Total since 2001 & 25 & 51 & -- & OECD Secretariat \\
\hline
\end{tabular}

Source: See fifth column for various sources.

14. It should be stressed that almost all estimates conducted so far refer to the total costs of moving from the existing situation to full compliance with EU standards. However, in the absence of EU accession, Poland would have continued to invest in the environmental field as required by domestic laws and regulations. Only one study so far, conducted by Kracow University of Economics, estimated the incremental cost of EU accession, i.e. the difference between the costs of compliance with domestic laws and with the EU requirements. For the large combustion plants, indeed, the lion share of total cost could have been attributed to external requirements, although Poland would have to adjust its laws anyway to comply with the international convention on trans-boundary pollution. This would have implied almost the same costs as the EU directive. For the directive on urban wastewater treatment the incremental annual cost of full compliance would be very small -- only 2 -11 pe rcent more than the cost of meeting quite restrictive Polish standards (Kracow University of Economics and Grontmij, 1995). 
36. Second, choosing appropriate environmental policy instruments can reduce accession costs. Most national environmental laws in EU countries have been issued based on European Directives that determine overall goals as well as procedural, institutional, and reporting requirements, but are less specific with respect to the means of achieving the goals. There are usually a few ways to transpose and implement a Directive. Whenever there is flexibility in choosing the instruments of implementation, it is worth exploring what is the cheapest way to achieve goals prescribed in a Directive. In particular, application of economic instruments can minimize the overall cost (to the country or to the sector) by allocating most of the abatement efforts to those polluters that can do it most cheaply. The costs of implementation of air pollution abatement and municipal solid waste management Directives are particularly sensitive to the choice of instruments. Box 8 shows how economic instruments can result in cost-effective solutions to reduce pollution from large combustion plants. Admittedly, economic instruments are often less predictable with respect to achieving environmental goals than standards. The European Commission needs to be convinced that each implementation strategy is credible and effective in protecting the environment. Therefore, the application of economic instruments in the EU accession process must be proceeded with a careful design in order to demonstrate convincingly that environmental objectives of a Directive will be achieved. This may be a difficult task for Poland, as there is little room for trials-anderrors in the accession process. However, the stake should be worth the effort.

\section{Box 8. How to abate pollution from large combustion plants in a cost-effective manner?}

The EU Large Combustion Plant (LCP) Directive and the Second Sulphur Protocol require that Poland reduce total emission of sulphur dioxide (substance contributing to so-called "acid rain") to meet national ceilings for 2000, 2005 and 2010 ("national targets"). The authorities must also ensure that power plants and other large combustion plants $\left(>50 \mathrm{MW}_{\text {th }}\right)$ meet specific, individual emission limit values ("emission standards"). All new plants must comply immediately and existing plants by mid-2004. This can be achieved in a cost effective manner. The Protocol allows to minimise the total investment cost by concentrating the emission reduction mainly in the plants where it can be done in the cheapest way. The Protocol also explicitly allows exemptions from the "emission standards" for some existing plants where abatement costs would be excessive. In Poland, studies have demonstrated that relaxing the requirement for plant level emission standards could decrease the total investment required to meet the national $\mathrm{SO}_{2}$ emission ceiling of the Second Sulphur Protocol by 2010 from $\$ 3.5$ billion to $\$ 1.5$ billion. Saving in total annualised cost would amount to $\$ 360$ million a year (EnergySys, 1997). Similar exemptions from some provisions of the LCP Directive have also been granted by the EU Council of Ministers to Spain.

37. Third, costs can also be reduced by focussing on environmental quality objectives rather than on individual technological requirements. Concentrating on ambient quality objectives encourages to formulate alternative strategies and compare their costs and benefits. This provides greater flexibility in the choice of solutions than under rigid technical requirements. In the water sector, for example, compliance costs can be reduced by using an appropriate sequencing of investments during the transition period and focusing on water quality objectives first, rather than on building water treatment facilities in each hamlet. Kindler et al. (1998) have demonstrated that a few well-located water treatment plants in the Upper Odra river basin could achieve improvements in water quality similar to those that would be achieved by building water treatment plants in all towns of more than 2000 persons (as required by the EU Directive on urban wastewater treatment plants) at only 60 per cent of the cost. Paying an additional 40 per cent of the cost would not bring commensurate improvements in water quality One cost-effective solution is therefore to develop investment strategies for all river basins that would guarantee improvements in water quality. In this regard, Poland requested a transition period during which the EU legislation would not be complied with to the letter. 
38. Hence, provided that these three factors of cost-effectiveness are fulfilled, the overall bill implied by accession would not be excessive. Assuming cost-effective implementation and reasonable transition periods, the current level of annual environmental investment would have to be raised by only 20-30 per cent in the years 2001-2005 (Zylicz, 1999, Berbeka, 1999) ${ }^{15}$ to comply with EU requirements. Disregarding cost-effectiveness or significantly shortening transition period would require a much steeper increase in investment requirements. Equally important will be to re-arrange priorities for public investment expenditure. An overall reallocation of public spending away from large air polluters (which are already close to EU requirements) to low air emissions sources, as well as to waste and water pollution, seems inevitable. ${ }^{16}$

39. Thus, assuming adequate policies, financial challenges are significant, but manageable. The small increase in investment required in the near future could be financed through a combination of several actions. The most obvious source of financing is the pre-accession assistance from the EU. But all EU subsidy schemes (ISPA, Phare, SAPARD) taken together can only increase the current spending by up to 10 per cent. Much greater potential to mobilise additional finance lies in two additional sources: first, regulatory reforms to encourage private sector participation in environmental protection; second, increasing present tariffs for using the environmental infrastructure.

\section{Private sector participation}

40. Financing environmental investments will be all the more easier if the private sector is involved as a financier and/or provider of environmental services. The current policy and regulatory framework is evidently not adapted to attract private participation in public environmental infrastructure. For instance, at the end of 2000, only two municipal landfills and two waste-water treatment plants were partially owned and operated by strategic private investors. In stark contract, in the Czech Republic and Slovakia most of the modern landfill capacity (more than 20 projects) conforming with the EU Landfill Directive are built and operated by international private sector companies. In Hungary, seven municipal water companies and eight municipal waste management are partially owned and their investments financed by large foreign companies $^{17}$. In Slovenia, by 1977 at least 12 municipalities had privatised communal services either through concessions or joint ventures with private companies (Mrak, 1998). This marks a tremendous difference in investment climate given the fact that Poland has more inhabitants (hence wastewater and solid waste) than all these countries taken together.

15. This is determined as follows: assuming cost-effectiveness and a full compliance by 2015 , annual investment flows of $€ 1.6$ billion would be required. An estimated 75 per cent of the present level of investment expenditure (i.e. about $€ 1.7$ billion annually) is already allocated to projects that bring compliance with EU laws, just enough on average in the entire compliance period. However, cash flow simulations conducted by Zylicz and Berbeka, who have taken Directive-specific implementation timetables, indicated that if the historical trends in investment expenditure continued there would be a temporary deficit of finance for investments in the years 2000-2005.

16. This will require some changes in the policy and legal basis of operations of Environment Funds. For example, currently the revenue of $\mathrm{SO}_{2}$ and $\mathrm{NO}_{\mathrm{x}}$ emission fees, which account for a lion share of total fee revenues are earmarked within Environment Funds for projects related to abatement of these two gasses. This provision will prevent the funds from increasing support to waste management or water treatment, even if all EU requirements on air pollution are implemented. Some environmental laws pending in Parliament contain even more rigid provisions for such an internal earmarking.

17. Data for Poland are expert estimates by Zbigniew Grabowski (waste) and Maciej Lorek (water) and for Hungary by Zsuzsanna Lehoczki form COWI Hungary. Data for Czech Republic and Slovenia come from the presentation by company Marius Pedersen at the PEPA meeting organized by the European Commission in November 2000. 
41. Obstacles to private sector participation include the low level of cost recovery through tariffs, and uncertainties in property rights. In addition, weak enforcement of environmental requirements with respect to public utilities, which operate depreciated and highly polluting wastewater treatment plants or landfills gives them unfair competitive advantage over private developers and operators, who are expected to comply with stringent standards and codes of conduct. This effectively discourages the latter ones from investing. Abundance of public subsidies seems also a barrier to significant private sector investments. These subsidies are usually not available on the same terms and conditions to private investors as to municipal public companies. Numerous experts and representatives of commercial banks have reported the cases where, for these reasons, city authorities rejected private financing even for projects that were commercially viable ${ }^{18}$.

\section{Tariffs}

42. Available studies suggest that a higher degree of cost recovery in expanded environmental infrastructure should not create an excessive burden for the majority of households if investment programmes are cost-effective and the implementation period is sufficiently long. For instance, the World Bank concluded that under low cost scenario, and if the investment is spread until 2015, the additional household water and wastewater bills should have a limited impact for most households ${ }^{19}$. Berbeka and Berbeka (1999), in a much more detailed study have concluded that if all the costs (annualised capital cost, operational and maintenance costs) were translated into higher tariffs, water and sanitation bill would become excessive for less than 10 per cent of the population. Shortening the transition period to below what Poland had requested (8-13 years for the urban wastewater treatment Directive and 8 years for the Directive on the quality of water for human consumption) would however not be affordable to many more households. Even in the most optimistic scenarios, selected vulnerable groups would need some support. The authors also noted a great difference between local water prices, and under-pricing of water and sanitation services in many municipalities. Pricing is also inefficient due to the perverse incentives conveyed through price subsidies (including reduced rates of effluent fees for municipalities). Targeted income support instead of blanket price subsidies would provide the right incentives to consumers to save water and would be more affordable to local budgets.

\section{Costs and benefits}

43. Poland's strategy with respect to the EU environmental requirements would be best formulated on the basis of a cost-benefit analysis (Box 9). State-of-the-art techniques of economic valuation of environmental benefits are rarely used in Poland. Environmental policy proposals of the Ministry of the Environment are usually not supported by robust economic arguments and often fail to require that other Ministries integrate environmental externalities in their projects and policies. Arguably, cost-benefit analysis is still in its early age and conclusions cannot always be drawn with a sufficient degree of

18. In addition, the national strategy for ISPA had not been agreed by the government and released to the public by end-2000, even though the first project pipeline was approved and the second was underway. This also appears to contribute to delaying investments in municipal environmental infrastructure.

19. What the households can afford, should be assessed on case by case basis. However, there are some internationally recognised benchmarks, used for example by EBRD and the World Bank in evaluating revenue risk in infrastructure projects in medium to low income countries. The maximum affordable share of water and sewerage bill in the household disposable income is considered to be 3 per cent to 4 per cent, the share of heating 5 per cent to 6 per cent and of electricity 7 per cent to 8 per cent. For a limited time individual shares can be higher, provided that the total utility bill does not exceed 15 per cent to 20 per cent of the household income. 
certainty. Some economic valuation studies compatible with the international standards have been conducted on the cost and benefit of achieving different environmental objectives, although most of them have had limited sectoral and geographical coverage ${ }^{20}$. Recently Poland was included in a comprehensive assessment of the benefits arising from compliance with the EU Environmental Acquis (EDC/EPE, 1999). The authors of this study found that the quantified benefits of air quality improvement exceeded the costs. In contrast, the quantified benefits of improved water quality are slightly lower than the cost estimate. The results however are very sensitive to a number of assumptions and uncertainties. Therefore the authors have concluded that it was not possible to state conclusively whether the overall benefits of compliance with the air and water directives exceed their respective costs.

\section{Box 9. How to assess the economic benefits of environmental policies?}

Economics offers a set of tools to evaluate the impact of environmental policies. Examples of such tools are cost-benefit analysis (CBA) and incidence analysis. The former can provide information on the net social gain of a policy or project, while the latter can explicitly reveal who gains and who loses. CBA is a standard technique of economic appraisal of policies and projects that have important social consequences (positive and negative), not manifested through prices on existing markets. Many OECD countries use CBA to support (but not to substitute for) rational government decision making (OECD, 1995c). International Financial Institutions routinely use CBA to appraise the economic (not financial) viability of large investment projects and structural loans. Incidence analysis should ideally capture not only the direct welfare or competitiveness impacts, but also the distribution of impact in the economy through general equilibrium price adjustments.

Usually, costs are easier to measure than benefits. Attributing explicit monetary values to benefits -- such as the value of life saved, diseases avoided or improved beauty of the landscape -- is difficult to accept for some people. However, measuring benefits in terms of monetary value help to base policy decisions on transparent and rational criteria. For example, decision makers usually know in monetary terms the private (internal) benefits and costs associated with individual projects or development programmes. But information on social benefits and costs are presented in general terms, or at best in physical units.

Without proper information on its economic value, the environment tends to be disregarded, even if it could have been protected on the grounds of economic efficiency. State-of-art techniques of estimating the economic value of the environment are rooted in the theory of welfare economics and reveal the "shadow" prices of environmental goods and services. These techniques are based on the evaluation of people and firms' "willingness to pay" for an improved quality of the environment, or "willingness to accept" a monetary compensation for tolerating environmental damages. This can be done indirectly, by observing how changes in the level of environmental goods and services affect prices in existing markets (e.g. adjustment to prevention expenditure, hedonic pricing, travel cost techniques) or directly, through revealing preferences for certain goods and services provided by environment (contingent valuation or experimental methods).

44. It is however clear that the cost of investments needed to reduce the release of nutrients nitrogen and phosphorus in the Baltic Sea will greatly exceed benefits. The study by Gren et al. (1996) analysed all Baltic bordering countries and found that all transition economies (except Russia) are likely to be net losers of the Baltic clean up programme with aggregated net losses of about $€ 1.2$ billion. Poland will lose the most (about $€ 630$ million net loss). In contrast, all EU member countries, in particular Sweden, will be significant winners, gaining altogether net benefits valued at $€ 1.3$ billion. This allocation of costs and benefits would justify the transfer of financial support from EU member states to transition economies in

20. Krupnick et al. (1995) conducted valuation of health impact of improved quality of ambient air using benefit transfer approach. Żylicz et al. (1994) used contingent valuation technique to investigate the willingness to pay for the improvement of the water quality in the Baltic Sea. Berbeka and Peszko (1997) applied the Contingent Valuation Method (CVA) to measure the value of benefits of restraining car traffic in the medieval centre of Krakow. 
order to share the burden of achieving common benefits. Similarly, it is clear that investments to reduce sulphur dioxide emissions from high stacks would benefit the whole of Europe, but the financial cost would have to be borne essentially by the Polish population. However, in return, the Polish population can expect benefit from similar efforts undertaken by Germany, Czech Republic and other foreign sources of acid rain that is deposited in Poland.

\section{Concluding remarks and recommendations}

45. Poland has achieved considerable progress over the last decade in containing the most pressing pollution problems. Nonetheless, there are signs that this early progress may fade away in the absence of far-reaching policy changes. The main challenge for the future will be to formulate sustainable development policies that are both environmentally effective and market friendly. This will require introducing a number of reforms in environmental policy.

46. Institutional reform would be a key step in making environmental policies more effective. The implementation of environment policies has been appropriately devolved to the right level of the government. Nevertheless, the multiplicity of actors has a price. It bears the risk of insufficient coordination and duplication in actions. Clarity in the mandates and objectives of the various actors as well as consistency between tasks and instruments is therefore essential. It is also crucial to integrate environmental objectives in the policies formulated by all Ministries - in particular with respect to energy, taxes, and industrial restructuring. Already, an inter-ministerial task force plays a role in fostering some environmental initiatives within the government. But the authorities need to nurture a dialogue within the government on the choice of ecological targets and the appropriate means to reach them. For instance, the role of energy policy in achieving higher air quality would need to be clarified, with a more prominent role devoted to renewable energy sources. Involving representatives of other government agencies and enterprises besides environmental experts at every step would help to build a sense of "ownership" among all actors.

47. Poland's progress in abating pollution owes a lot to its historically adequate mix of policy instruments. Evolving for about 20 years together with the market reforms and liberalisation of energy prices, it has induced large and growing investment flows in environmental protection equipment and has helped cut emissions of most pollutants in the first years of transition. Nonetheless, the present mix is now becoming less effective to address the remaining pollution, which is more costly to abate. In addition, it relies excessively on subsidies, which undermines its efficiency and may soon become unaffordable for the government budget. Except for new product charges and deposit-refund systems, there have been few innovations in environmental policy in recent years. A reform of the mix of instruments is therefore necessary.

48. The current mix is, in any case, likely to be challenged by the transposition of EU legislation, which relies heavily on "command and control" instruments, in particular technical standards. International experience shows that policy instruments should stay away from over-reliance on technical standards, which impose excessive costs on the economy and create distortions to trade and competition. The goal should be to find a mix of environmental policy instruments that achieve a delicate balance between ecological effectiveness and market friendliness. Thus, Poland should carefully phase in permits based on technology standards as required by EU, to replace permits oriented on environmental quality standards. Competitiveness and trade effects of BAT-based standards and their contribution to environmental quality goals will need to be closely monitored. In addition to the "command and control" instruments, Poland should continue to develop well-designed economic instruments such as environmentally-related taxes and trading of emission permits. In particular, the authorities could take advantage of their ongoing tax reform to "green" the tax system. Excise taxes on fossil fuels in particular should be harmonized in terms of carbon content, which would involve introducing an excise tax on coal -- the dirtiest source of energy. The 
present system of emission fees has well served its purpose but should be reformed, as it is complex to administer and collect. The authorities should decide which of the 62 air emission fees are really important, raise their rates to make them more environmentally effective. Most others could be scrapped. It would be essential to maintain the present level-playing-field in the collection of environmental fees and avoid introducing elements of discretion, as this can only reduce arms-length relations with polluters.

49. The role of Environment Funds needs to be reconsidered. To provide true value added to financing environmental investments the Funds should be de-politicised and need to radically improve cost-effectiveness of their project portfolios. They need to follow EcoFund and Krakow Regional Fund examples and introduce transparent and rigorous project selection criteria and procedures. More strategically, as the period of transition draws to an end, market-based sources of financing are becoming available for well-designed environmental protection investments. Hence, the need for Environment Funds providing subsidised resources to polluters is much less justified. With improved financial and capital markets and strengthened enforcement of environmental regulations, environmental investments will increasingly be seen as ordinary investments requiring financing but eventually paying for themselves. Save exceptional cases, such as provision of public goods or significant external benefits, there are no reasons why environmental investments should receive a special treatment if they are considered as part of "good practices" and if people value clean environment. Hence, the Funds should be phased out within a reasonable time period. Until then, they could play a key role in the environmental protection investment effort required by accession to the European Union. This would call for targeting their mandates more narrowly on accession related investments. Funds should be vehicles for leveraging additional finance from private and foreign sources and carefully avoid substituting for and crowding-out other financing institutions.

50. Accession to the European Union will require large investments in order to bring water and air emissions, as well as waste disposal, in line with permissible levels. These large investments are both affordable and financeable as long as they are made i) in a cost-effective manner, ii) with greater private sector participation, and iii) along with higher cost recovery ratios. If these three criteria are fulfilled, a relatively small increase in present expenditure should be sufficient to achieve EU standards. Cost effectiveness requires development strategies utilising the flexibility provisions included in many directives. Appropriate use of economic instruments can also significantly decrease compliance costs, by concentrating investment efforts on those plants where abatement costs are the lowest. Wider participation of private sector in developing public environmental infrastructure will require regulatory and policy reforms enabling the entry of private investors into this market, and levelling the playing field in environmental enforcement and finance. Raising tariffs for using the environmental infrastructure - in particular municipal tariffs for consuming water and releasing wastewater - is also essential. Bringing cost recovery ratios closer to international standards would not only reduce water usage, but it would also create a necessary condition to attract private and foreign finance. This should not cause an undue burden for most households, and targeted support can be envisaged for low-income households. Alternative approaches are always possible, but they would be costly for Poland's already stretched benefits and would require to cut back other government priorities.

\section{Box 10. Recommendations on environmentally sustainable growth}

Integrate environment protection with other policies

- Review existing tax system to phase out environmentally harmful incentives and equalise energy taxation in terms of carbon content.

- Where technically feasible, use Cost-Benefit Analysis to support appraisal of major government projects and policies (for instance in transport, energy and agriculture). Ensure adequate incorporation of environmental external effects into the analysis.

(continued on next page) 
- Ensure effective integration of environmental considerations in the most sensitive sectoral policies, in particular for industry, mining, transport and agriculture through adequate policy and regulatory framework.

Improve co-ordination and effectiveness of institutions

- Clarify roles and responsibilities of different government institutions in environmental policy in particularly at the Poviat and Voivodship levels.

- Review draft Water Law and draft Law on Environmental Protection in order to transfer responsibility of investment programmes to River Basin Management units.

$\underline{\text { Select an appropriate mix of instruments }}$

- Review the draft Law on Environmental Protection to provide the legal basis for tradable emission permits; develop regulatory framework for rules and modalities of domestic emission trading systems.

- Streamline the environmental objectives of air emissions fees. Identify which of the 62 fees should provide genuine incentives. Phase out those fees that play neither incentive nor revenue raising role adequately.

- Phase out reduced rates of environmental fees for selected polluters, in particular of wastewater fees for municipal waste water treatment plants.

\section{Ensure that environmental protection investments are financed}

- Introduce the Polluter Pays Principle defined according to the original OECD "no-subsidy" philosophy to key policy documents and legal acts. Review all draft laws to eliminate provisions for excessive subsidies, which starkly violate the polluter pays principle.

- Remove obstacles to and create conducive conditions for private sector participation in the development and management of public environmental infrastructure

- Formulate a strategy for phasing out Environment Funds, for example by tying their operations to the implementation of the most investment-heavy EU environmental Directives. Define specific and targeted eligibility criteria for projects to be supported by Funds. Establish and enforce clear criteria for the operations of the Funds, including cost-effectiveness, transparency, accountability, and others listed in St. Petersburg Guidelines. Review existing laws and new draft laws to eliminate provisions earmarking environment fees and fines within Environment Funds.

\section{Prepare for EU accession}

- Prepare realistic implementation and financing strategies for most investment-heavy directives. Pay particular attention to minimising the costs of attaining environmental quality targets, e.g. by incorporating economic instruments into implementation strategies where appropriate.

- For the Urban Waste Water Directive: i) develop least-cost investment plans using the Upper Odra plan as a reference; ii) identify the water bodies which are not sensitive to eutrophication in order to avoid expensive high level removal of nutrients where it is not justified by environmental and social benefits; and iii) avoid construction of centralised sewerage systems where the costs would be excessive compared to benefits.

- For Nitrates Directive, review and eliminate environmentally perverse incentives in the agriculture policy. 


\section{BIBLIOGRAPHY}

Atmoterm (1996),

"Tradable Emission Permit System", in Proceedings from Marketable Permit Workshop, HIID (Harvard Institute for International Development) and (Polish) Ministry of Environment, Jadwisin (Poland), pp. 14-17.

Barde, J-P. (1991),

Valuing the Environment, Six Case Studies, Earthscan Publications Ltd., London.

Berbeka K. (1999),

Próba określenia ram finansowych dla Sredniookresowych Strategii Sektorowych i Narodowego

Planu Rozwoju, Report submitted by The Regional Environmental Center to the Ministry of

Environmental Protection under the project PHARE 4.2

Berbeka K., and J. Berbeka, (1999),

Impact of Implementation of the Following Directives: on Urban Wastewater Treatment Plants and on the Quality of Drinking Water on Households' Budgets in Poland, Report submitted by The

Regional Environmental Center to the Ministry of Environmental Protection under the project PHARE 4.2

Berbeka, K. and Z. Grabowski (1999),

Koncepcja krajowego programu gospodarki odpadami i wdrożenia wymagań prawa europejskiego w tym zakresie. Maszynopis. Kraków.

Berbeka, K. and G. Peszko (1997), Monetary Valuation of Benefits of Traffic Calming in the Old City of Kraków - A Contingent Valuation Study; Centre for Social and Economic Research on the Global Environment at the University College, London, UK.

EDC Ltd. and Environmental Policy Europe (1997),

Compliance Costing for Approximation of EU Environmental Legislation in the CEEC, Brussels, Belgium.

EDC Ltd. and Environmental Policy Europe (1999),

Approximation of Environmental legislation: A Study of the Benefits of Compliance with the EU Environmental Acquis. Report to the European Commission, Brussels.

Energoprojekt (2000),

Raport nt. prawnych i ekonomicznych uwarunkowan wdrozenia dyrektywy 88/609 EWG z dnia 24 listopada 1988 w sprawie ograniczenia emisji niektórych zanieczyszczen do powietrza z duzych obiektow energetycznego spalania paliw, Warszawa. 


\section{ECO/WKP(2001)25}

EnergySys (1997),

Compliance with the European Union Air Pollution Emission Standards. Cost of Alternative Strategies for Reducing Sulphur Emissions, Warsaw.

European Commission (1998),

Communication from the Commission to the Council, the European Parliament, the Economic and Social Committee, the Committee of the Regions and the Candidate Countries in Central and Eastern Europe on Accession Strategies for Environment : Meeting the Challenge of Enlargement with the Candidate Countries in Central and Eastern Europe, COM/98/0294.

Fiedor B., S. Czaja, A. Graczyk and Z. Jakubczyk (2000)

Ocena efektywności działania handlu pozwoleniami na emisję na przykładzie emisji $\mathrm{SO}_{2} \mathrm{w}$ elektroenergetyce i propozycje wdrożenia rozwiazań do prawodawstwa polskiego w tym zakresie, Wroclaw Academy of Economics.

Gorka, K. et. al. (1997),

"Wymagania ochrony środowiska a konkurencyjność przedsiębiorstw." In: Szanse i zagrożenia rozwoju przedsiębiorstw w Europie Środkowej i Wschodniej. AE, Poznań, pp. 85-92.

Gren, I., T. Soderqvist, F., Wulff, F., Langaas, S., Sandstrom, M. and Folke, C. (1996), Reduced Nutrient Lads to the Baltic Sea: Ecological Consequences, Costs and Benefits, Beijer Discussion Paper Series No. 83, Beijer International Institute of Ecological Economics, The Royal Swedish Academy of Sciences.

GUS (Central Statistical Office) (2000),

Environment 2000, Information and statistical papers, Warsaw.

Karaczun, Z. and G. Peszko (1999),

Koncepcja krajowego programu gospodarki wodno-ściekowej i wdrożenia wymagań prawa europejskiego w tym zakresie. Maszynopis. Warszawa.

Kindler, J., M. Roman, A. Nalberczynski, S. Tyszewski, D. Puslowska, H. Kloss-Trebaczkiewicz, E. Osuch-Pajdzinska and M. Gromiec (1998),

"Balancing costs and water quality in meeting EU directives (the Upper/Middle Odra case study in Poland)", Water Policy, pp. 283-303.

Klaassen, G. (1996),

"Emission Trading and the EU IPPC Directive", in HIID (Harvard Institute for International Development) and Polish Ministry of Environment Marketable Permit Workshop, Proceedings, Jadwisin (Poland), pp. 24-26.

Krakow University of Economics, Grontmij (1996),

Development of Cost Methodologies and Evaluation of Cost-Effective Strategies for Achieving Harmonisation with EC Environmental Standards, Phare Project EC/EPP/91, Krakow.

Krakow University of Economics (1998),

Cost assessment of implementation of EU legislation in Poland in the field of waste management.

Department of Industrial and Environmental Policy, Krakow.

Krakow University of Economics (1999),

Analiza skuteczności działania instrumentów ekonomicznych ochrony środowiska w Polsce, report for the Ministry of Environment, Krakow. 
Krupnick, A., K. Harrison, E. Nickell and M. Toman (1995),

"The Value of Health Benefits from Ambient Air Quality Improvements in Central and Eastern Europe: An Exercise in Benefits Transfer", Environmental and Resource Economics 7: 307-332, 1996.

Markowska, A. and T. Żylicz (1996),

Costing an international public good: the case of the Baltic Sea, paper presented at the Annual Conference of the European Association of Environmental and Resource Economists in Lisbon, June.

McLean, B. (1996),

"The US Clean Air Act Title IV Acid Rain Programme - Description, Benefits, Realities, Lessons Learned", in HIID (Harvard Institute for International Development) and Polish Ministry of Environment, Marketable Permit Workshop, Proceedings, Jadwisin (Poland), pp. 27-33.

Ministry of Economy (1998),

Restructuring Programme for Polish Steel Industry, Warsaw, June.

Ministry of Economy, Ministry of the State Treasury (2000),

The Environmental Assessment Study of the Hard Coal Sector, Katowice.

Ministry of the Environment (1999),

A Concept of the National Investment Programme for Implementation of the EU Environmental Regulations in the Field of Waste Management, Berbeka, K. and Z. Graboski.

Ministry of the Environment (2000),

Management of the resources in the funds of environmental protection and water management in 1998 and 1999, Ministry of Environment, Warsaw.

Mrak, M. (1998), Communal Infrastructure in Slovenia: Survey of Investment Needs and Policies Aimed at Encouraging Private Sector Participation, mimeo prepared for the Harvard University.

NFOS (1998),

Strategic Directions and Methods of Development of the National Fund for Environmental Protection and Water Management, adopted by the Ministry of Environment in December.

OECD (1992)

The Polluter-Pays Principle, OECD Analyses and Recommendations, Paris.

OECD (1995a),

Environmental Performance Review of Poland, OECD, Paris.

OECD (1995b),

The St Petersburg Guidelines on Environmental Funds in the Transition to a Market Economy, Paris. OECD/GD(95) 108.

OECD (1995c),

The Economic Appraisal of Environmental Projects and Policies, OECD, Paris.

OECD (1998),

Economic Globalisation and the Environment, Paris. 
OECD (1999), Voluntary Approaches for Environmental Policy: An Assessment, OECD, Paris.

$\operatorname{OECD}(2000 a)$,

Economic Survey of Canada, Paris.

OECD (2000b),

Frameworks To Measure Sustainable Development, Proceedings of the OECD Expert Workshop, OECD, Paris.

OECD $(2000 c)$,

Towards Sustainable Development: Indicators to Measure Progress, Proceedings of the OECD Rome Conference, Paris.

Peszko, G. (1996),

"Emission Trading as a Potential Instrument of Compliance with the Second Sulphur Protocol by the Power Sector in Poland", in Proceedings from Marketable Permit Workshop, HIID (Harvard Institute for International Development) And (Polish) Ministry of Environment, Jadwisin (Poland), pp. 18-23.

Peszko G. (1998),

Analysis and assessment of compliance of procedures and regulations of environmental funds with the EU guidelines on state aid to environment, report for the Department of Environmental Policy and European Integration of the Ministry of Environment, Warszawa (in Polish).

Peszko, G. (1999),

"Polish Experience with Environmental Fees, Fines and Taxes, and Simulations of Some Economic Effects of Elements of Green Tax Reform Using the Computable General Equilibrium Model", in Kai Schlegelmilch (Ed.), Green Budget Reform in Europe, Springer.

TME (Institute for Applied Environmental Economics) (1999),

Costs of Compliance with EU Environmental Directives in Poland, Final report submitted to the Polish Ministry of Environmental Protection, Natural Resources and Forestry, (Phare DISAE POL110).

United Nations (1993), Integrated Environmental and Economic Accounting, Sales No. E.93.XVII.12., New York: United Nations.

Wajda, S. (2000),

"Harmonisation - the commitment to change", paper presented at the conference in Budapest, 1213 June 2000, mimeo.

Warsaw University (2000),

Economic and Environmental Analysis of projects financed by the National Fund of Environmental Protection and Water Management, report submitted to the Department of Environmental Policy and European Integration of the Ministry of Environment, Warsaw.

World Bank (1997),

Expanding the Measure of Wealth: Indicators of Environmentally Sustainable Development, Environmentally Sustainable Development Studies and Monographs Series No. 17. Washington, DC. 
World Bank (2000),

Poland - Complying with the EU Environmental Legislation, World Bank Technical Paper No. 454, prepared by Gordon Hughes and Julia Bucknall, Washington DC.

Żylicz, T. (1997),

Social and Economic Consequences of Approximation with the European Union (EU) in the Environmental Field, mimeo, Warsaw.

Żylicz T. (1999),

Szacunkowa ocena przeplywów finansowych w zwiąku z wdrażaniem acquis communautaire. Maszynopis. Warszawa.

Żylicz, T., I. Bateman, S. Georgiou, A. Markowska, D. Dziegielewska, K. Turner, A. Graham and I. Langford (1994),

The Baltic Drainage Basin Project: Contingent Valuation of Eutrophication Damage in the Baltic Sea Region, CSERGE Working Paper GEC 94-03.

Żylicz, T. and J. Raczka (2000),

Analysis of the compliance of the Polish system for state aid to environmental measures in the enterprise sector with the EU Guidelines, report for the Department of Environmental Policy and European Integration of the Ministry of Environment, Warsaw (in Polish). 
ECO/WKP(2001)25

\section{ECONOMICS DEPARTMENT \\ WORKING PAPERS}

298. Tracking the Euro

(June 2001) Vincent Koen, Laurence Boone, Alain de Serres, Nicola Fuchs

297. Firm Dynamics and Productivity Growth: A Review of Micro-evidence from OECD Countries (June 2001) Sanghoon Ahn

296. How should Norway Respond to Ageing? (May 2001) Pablo Antolín and Wim Suyker

295. How will Ageing Affect Finland?

(May 2001) Pablo Antolín, Howard Oxley and Wim Suyker

294. Sectoral Regulatory Reforms in Italy: Framework and Implications

(May 2001) Alessandro Goglio

293. Encouraging Environmentally Sustainable Growth: Experience in OECD Countries (May 2001) Paul O'Brien and Ann Vourc'h

292. Increasing Simplicity, Neutrality and Sustainability: A Basis for Tax Reform in Iceland (May 2001) Richard Herd and Thorsteinn Thorgeirsson

291. Options for Reforming the Tax System in Greece (April 2001) Chiara Bronchi

290. Encouraging Environmentally Sustainable Growth in Canada (March 2001) Ann Vourc'h

289. Encouraging Environmentally Sustainable Growth in Sweden (March 2001) Deborah Roseveare

288. Public Spending in Mexico: How to Enhance its Effectiveness (March 2001) Bénédicte Larre and Marcos Bonturi

287. Regulation in Services: OECD Patterns and Economic Implications (February 2001) Giuseppe Nicoletti

286. A Small Global Forecasting Model (February 2001) David Rae and David Turner

285. Managing Public Expenditure: Some Emerging Policy Issues and a Framework for Analysis (February 2001) Paul Atkinson and Paul van den Noord

284. Trends in Immigration and Economic Consequences (February 2001) Jonathan Coppel, Jean-Christophe Dumont and Ignazio Visco

283. Economic Growth: The Role of Policies and Institutions.

Panel Data Evidence from OECD Countries

(January 2001) Andrea Bassanini, Stefano Scarpetta and Philip Hemmings 
282. Does Human Capital Matter for Growth in OECD Countries? Evidence from Pooled Mean-Group Estimates (January 2001) Andrea Bassanini and Stefano Scarpetta

281. The Tax System in New Zealand: An Appraisal and Options for Change (January 2001) Thomas Dalsgaard

280. Contributions of Financial Systems to Growth in OECD Countries (January 2001) Michael Leahy, Sebastian Schich, Gert Wehinger, Florian Pelgrin and Thorsteinn Thorgeirsson

279. House Prices and Economic Activity (January 2001) Nathalie Girouard and Sveinbjörn Blöndal

278. Encouraging Environmentally Sustainable Growth in the United States (January 2001) Paul O’Brien

277. Encouraging Environmentally Sustainable Growth in Denmark (January 2001) Paul O’Brien and Jens Høj

276. Making Growth more Environmentally Sustainable in Germany (January 2001) Grant Kirkpatrick, Gernot Klepper and Robert Price

275. Central Control of Regional Budgets : Theory with Applications to Russia (January 2001) John M. Litwack

274. A Post-Mortem on Economic Outlook Projections (December 2000) Vassiliki Koutsogeorgopoulou

273. Fixed Cost, Imperfect Competition and Bias in Technology Measurement: Japan and the United States (December 2000) Kiyohiko G. Nishimura and Masato Shirai

272. Entry, Exit, and Aggregate Productivity Growth: Micro Evidence on Korean Manufacturing (December 2000) Chin-Hee Hahn

271. The Tax System in Korea: More Fairness and Less Complexity Required (December 2000) Thomas Dalsgaard

270. A Multi-Gas Assessment of the Kyoto Protocol (October 2000) Jean-Marc Burniaux

269. The Changing Health System in France (October 2000) Yukata Imai, Stéphane Jacobzone and Patrick Lenain

268. Inward Investment and Technical Progress in the UK Manufacturing Sector (October 2000) Florence Hubert and Nigel Pain

267. Aggregate Growth: What have we Learned from Microeconomic Evidence? (October 2000) John Haltiwanger

266. Determinants of Long-term Growth: A Bayesian Averaging of Classical Estimates (BACE) Approach (October 2000) Gernot Doppelhofer, Ronald I. Miller and Xavier Sala-i-Martin

265. The Great Reversals: The Politics of Financial Development in the $20^{\text {th }}$ Century (October 2000) Raghuram G. Rajan and Luigi Zingales

264. Trade and Growth: Still Disagreement about the Relationship (October 2000) Robert Baldwin 